\title{
Disrupted $\mathrm{Cl}-$ homeostasis contributes to reductions in the inhibitory efficacy of diazepam during hyperexcited states
}

\author{
Tarek Z. Deeb, Yasuko Nakamura, Greg D. Frost, Paul A. Davies, and Stephen J. Moss \\ Department of Neuroscience, Physiology and Pharmacology, University College, London WC1E \\ 6BT UK; Tufts University, 136 Harrison Avenue, Boston, MA 02111, USA
}

\begin{abstract}
The $\mathrm{K}^{+}-\mathrm{Cl}^{-}$cotransporter $\mathrm{KCC} 2$ is the major $\mathrm{Cl}^{-}$extrusion mechanism in most adult neurons. This process in turn leads to $\mathrm{Cl}^{-}$influx upon activation of $\mathrm{GABA}_{\mathrm{A}}$ receptors and the canonical hyperpolarizing inhibitory postsynaptic potential. Several neurological disorders are treated with drugs that target and enhance $\mathrm{GABA}_{\mathrm{A}}$ receptor signaling, including the commonly used benzodiazepine diazepam and the anesthetic propofol. Some of these disorders are also associated with deficits in $\mathrm{GABA}_{\mathrm{A}}$ signaling and become less sensitive to therapeutic drugs that target $\mathrm{GABA}_{\mathrm{A}}$ receptors. To date, it is unknown if alterations in the neuronal $\mathrm{Cl}^{-}$gradient affect the efficacies of diazepam and propofol. We therefore used the in vitro model of glutamate-induced hyperexcitability to test if alterations in the $\mathrm{Cl}^{-}$gradient affect the efficacy of $\mathrm{GABA}_{\mathrm{A}}$ modulators. We exclusively utilized the gramicidin perforated-patch clamp configuration to preserve the endogenous $\mathrm{Cl}^{-}$gradient. Brief exposure to glutamate reduced the inhibitory efficacy of diazepam within five minutes that was caused by the collapse of the $\mathrm{Cl}^{-}$gradient, and not due to reductions in $\mathrm{GABA}_{\mathrm{A}}$ receptor number. Unlike diazepam, propofol retained its efficacy by shunting the membrane conductance despite the glutamate-induced appearance of depolarizing $\mathrm{GABA}_{\mathrm{A}}$-mediated currents. Similarly, pharmacological inhibition of $\mathrm{KCC} 2$ by furosemide disrupted $\mathrm{Cl}^{-}$homeostasis and reduced the efficacy of diazepam but not propofol. Collectively our results suggest pathological hyperexcitable conditions could cause the rapid accumulation of intracellular $\mathrm{Cl}^{-}$and the appearance of depolarizing $\mathrm{GABA}_{\mathrm{A}}$-mediated currents that would decrease the efficacy of diazepam.
\end{abstract}

\section{Keywords}

KCC2; propofol; glutamate; rat; neurons

\section{Introduction}

The type $2 \mathrm{~K}^{+}-\mathrm{Cl}^{-}$cotransporter $(\mathrm{KCC} 2)$ enables most adult neurons to generate an inwardly directed $\mathrm{Cl}^{-}$gradient that gives rise to hyperpolarizing $\mathrm{GABA}_{\mathrm{A}}$-mediated $\mathrm{Cl}^{-}$ currents and the canonical inhibitory postsynaptic potential (Thompson \& Gahwiler, 1989b; Payne, 1997). Long term deficits in KCC2 functional expression occur in a number of neurological disorders (Blaesse et al., 2009), including chronic epilepsy in humans and rats (Huberfeld et al., 2007; Pathak et al., 2007), ischemia (Galeffi et al., 2004; Papp et al., 2008; Jaenisch et al., 2010), and chronic pain (Coull et al., 2003; Lu et al., 2008; Wu et al., 2009). In some cases, these changes in $\mathrm{KCC} 2$ were associated with the accumulation of intracellular $\mathrm{Cl}^{-}$. Additionally, intense GABAergic activity can overwhelm functionally

Corresponding author and affiliations: Stephen J. Moss, Department of Neuroscience, Tufts University, Boston, MA, 02111, USA. Fax: 617636 3922. Stephen.Moss@tufts.edu. . 
intact $\mathrm{KCC} 2$ resulting in the phenomenon termed $\mathrm{Cl}^{-}$plasticity (Rivera et al., 2005), which is a temporary switch from hyperpolarizing to depolarizing GABAergic currents due to $\mathrm{Cl}^{-}$ loads (Thompson \& Gahwiler, 1989a; Fujiwara-Tsukamoto et al., 2010; Viitanen et al., 2010). Thus, at least two forms of perturbed $\mathrm{Cl}^{-}$homeostasis can impact $\mathrm{GABA}_{\mathrm{A}}$-mediated currents: brief periods due to increased $\mathrm{Cl}^{-}$channel activity, and prolonged periods due to impaired $\mathrm{KCC} 2$-mediated $\mathrm{Cl}^{-}$extrusion.

$\mathrm{GABA}_{\mathrm{A}}$ signaling is also regulated by receptor trafficking at the membrane surface, and changes in total protein and mRNA levels. Similar to the pattern observed with KCC2, changes in $\mathrm{GABA}_{\mathrm{A}}$ receptors are associated with a number of pathophysiological states, including drug-resistant epilepsy in humans (Loup et al., 2000), and after SE in rodents at the level of protein expression and trafficking (Naylor et al., 2005; Goodkin et al., 2008; Terunuma et al., 2008) as well as at the mRNA level (Brooks-Kayal et al., 1998). Further analysis utilizing combinations of biochemical and immunological techniques (Goodkin et al., 2005; Saliba et al., 2012) as well as single-particle tracking methods (Bannai et al., 2009; Niwa et al., 2012; Smith et al., 2012) have revealed that GABA $A_{A}$ receptors are rapidly and dynamically processed within minutes under hyperexcitable conditions in cultured neurons.

$\mathrm{GABA}_{\mathrm{A}}$ receptors are one of the most frequently targeted families of proteins for therapeutic intervention. $\mathrm{GABA}_{\mathrm{A}}$ receptors are the principle sites of action in the brain for benzodiazepines, which are administered for multiple disorders: diazepam and lorazepam are the first-line therapy to treat status epilepticus (SE) (Goodkin \& Kapur, 2009); the benzodiazepine alprazolam for anxiety, and the non-benzodiazepine $\mathrm{GABA}_{\mathrm{A}}$ modulator zolpidem as a sleep aid (Rudolph \& Knoflach, 2011). They are also the principle mediators of the general anesthetics pentobarbital and propofol (Orser et al., 2002), and mediate some of the actions of neurosteroids such as THDOC (Mody \& Maguire, 2011).

Considering the therapeutic pharmacology and dynamic properties of $\mathrm{GABA}_{\mathrm{A}}$ receptors, the factors that determine receptor signaling could have clinical relevance. We therefore tested the hypothesis that intracellular $\mathrm{Cl}^{-}$accumulation reduces the inhibitory efficacy of diazepam in dissociated rat hippocampal neurons. We exclusively utilized the gramicidin perforated-patch technique to preserve the endogenous $\mathrm{Cl}^{-}$gradient and to demonstrate that the inhibitory efficacy of diazepam fluctuates rapidly on the same intact neurons.

\section{Materials and methods}

\section{Animals}

Eighteen timed-pregnant female Sprague Dawley rats were used (Charles River International Inc., Wilmington, MA, USA). All animal procedures were performed in accordance with NIH and institutional guidelines, and were approved by the Institutional Animal Care and Use Committee of Tufts University.

\section{Cell culture}

All experiments were performed on cultured hippocampal neurons obtained from Sprague Dawley rat E18 embryos. Briefly, neurons were plated on glass coverslips coated with polyL-lysine in $35 \mathrm{~mm}$ dishes ( 5 coverslips per dish). Neurons were plated at a density of 250,000 per dish and maintained in Neurobasal media containing B27 serum-free supplement (2\%), glucose (0.6\%), GlutaMax supplement (1\%), penicillin $(1 \%, 50,000$ units), and streptomycin $(1 \%, 50 \mathrm{mg})$. Neurons were grown in an atmosphere with $5 \% \mathrm{CO}_{2}$ for 18-21 days prior to experimentation. We plated the neurons directly onto the coverslips in the maintenance media, we did not utilize a serum-containing solution for cell adhesion, nor did we use a glial feeding layer. All cell culture materials were purchased from Invitrogen. 


\section{Solutions and drugs}

All recordings were performed using the perforated patch-clamp technique. We used gramicidin D (50 $\mu \mathrm{g} / \mathrm{mL}$, Sigma) to establish access resistances between 40-60 M $\Omega$ throughout the recording period. All recordings were performed at $34^{\circ} \mathrm{C}$. The recording pipettes were filled with saline containing (in $\mathrm{mM}$ ) $140 \mathrm{KCl}$ and $10 \mathrm{HEPES}, \mathrm{pH} 7.4 \mathrm{KOH}$. Bath saline contained (in mM) $140 \mathrm{NaCl}, 2.5 \mathrm{KCl}, 2.5 \mathrm{CaCl}_{2}, 1.2 \mathrm{MgCl}_{2}, 10$ HEPES, 11 glucose, $\mathrm{pH}$ 7.4 NaOH. Stocks of bicuculline, bumetanide, DNQX, furosemide and propofol were dissolved in DMSO ( $0.1 \%$ final concentration), glutamate in $1 \mathrm{M} \mathrm{HCl}$ (in saline, balanced with v/v $1 \mathrm{M} \mathrm{NaOH}$ ) and AP5 in $1 \mathrm{M} \mathrm{NaOH}$ (in saline, balanced with v/v $1 \mathrm{M} \mathrm{HCl}$ ); all of these compounds except propofol were purchased from Tocris Bioscience. Propofol was purchased from Sigma Aldrich. Diazepam solution $(5 \mathrm{mg} / \mathrm{mL}$, purchased from Hospira Inc., Lake Forest, IL, USA) was dissolved directly into saline. We used a three-barreled (0.7 $\mathrm{mm}$ diameter per barrel) glass perfusion pipette (Warner Instruments) placed just above the target neuron to apply all compounds and control saline. These solutions were applied through the perfusion pipette at a rate of $0.5 \mathrm{~mL} / \mathrm{min}$ and we used a computer controlled perfusion fast-step device (Warner Instruments LLC, Hamden, CT, USA) to ensure fast and complete exchange of solutions. To ensure that solutions equilibrated faster, we did not have the bath inlet pipe flowing, the only source of solution was the perfusion pipette.

\section{Electrophysiology}

We used voltage-ramp protocols to determine the reversal potential of muscimol activated currents $\left(\mathrm{E}_{\mathrm{GABA}}\right)$. We first performed a voltage-ramp in the absence of muscimol to measure the background leak currents, followed $10 \mathrm{~s}$ later by a second voltage-ramp in the presence of muscimol. We performed off-line leak subtraction to isolate the muscimolactivated currents, which we plotted against the holding potential to obtain I-V relationships. We then obtained $\mathrm{E}_{\mathrm{GABA}}$ values from linear regression fits to the leak-subtracted data at voltages near the observable reversal potential. We ramped the holding potential from -100 to $-70 \mathrm{mV}$ or -90 to $-60 \mathrm{mV}(20 \mathrm{mV} / \mathrm{s})$ when muscimol was hyperpolarizing and we ramped the holding potential from -60 to $-30 \mathrm{mV}(20 \mathrm{mV} / \mathrm{s})$ when muscimol was depolarizing. We used these two different protocols to limit perturbations in $\mathrm{Cl}^{-}$homeostasis that can be caused by the abnormally large driving forces on muscimol-activated currents in voltage-clamp mode. Input resistance values were obtained in current-clamp mode by using a series of $1 \mathrm{~s}$ current steps ( -80 to $+80 \mathrm{pA}, 20 \mathrm{pA}$ jumps) spaced $2 \mathrm{~s}$ apart; subthreshold voltage responses were then plotted against the current steps, and the data points were fit by linear regression analysis to obtain input resistance values. All data were obtained with an Axopatch 200B amplifier and pClamp 10 software (Molecular Devices LLC, Sunnyvale, CA, USA), and analyzed offline using Clampfit. All records were filtered at $2 \mathrm{kHz}$ and digitized at $10 \mathrm{kHz}$.

\section{Selection criteria of neurons}

We chose only pyramidal-shaped neurons. Due to the variability of cultured hippocampal networks we used selection criteria, if neurons did not meet all of these criteria they were discarded. Neurons had to maintain membrane potential values less than $-50 \mathrm{mV}$ in $\mathrm{I}=0$ mode to ensure health; neurons had to reestablish membrane potential values less than -50 $\mathrm{mV}$ within 1 min after exposure to glutamate to ensure proper function of the $\mathrm{Na}^{+} / \mathrm{K}^{+}$ ATPase; neurons had to fire at least 10 APs per minute under basal conditions and after washout of furosemide or glutamate to prevent biasing the inhibitory efficacy of diazepam and propofol; and neurons had to exhibit GABAergic hyperpolarizing postsynaptic potentials and muscimol responses under basal conditions. We interleaved particular sets of experiments on the same batches of primary cultured neurons to limit the influence of different dissections: glutamate/diazepam (group 1) with glutamate/propofol (6 dissections), 
furosemide/diazepam with furosemide/propofol (4 dissections), glutamate/diazepam (group

2) with glutamate $+\mathrm{Cl}^{-}$uptake inhibitors/diazepam (3 dissections).

\section{Sequence of electrophysiological protocols}

In this section, modulator refers to diazepam or propofol. All of the data are presented as replicates of experiments performed on the same rat cultured hippocampal DIV18-21 day neuron both before and after the treatment with glutamate, furosemide, bumetanide, or carbachol. None of the data was obtained from a neuron exclusively before or after these exposures. The efficacy of the modulators was measured on all cells, but $\mathrm{E}_{\mathrm{GABA}}$ and input resistance measurements were not made on every cell tested. The neurons were patched and monitored for basal activity in order to determine if they met the selection criteria as mentioned in the preceding section. After this initial period, the following sequence was performed for cells exposed to glutamate: 1) measure the input resistance in current-clamp mode, 2) measure APs for $1 \mathrm{~min}$ in I=0 mode, 3) apply modulator for $2 \mathrm{~min}$ and measure APs during the last minute in $\mathrm{I}=0$ mode, 4 ) measure the input resistance in the continued presence of modulator in current-clamp mode, 5) washout modulator for $5 \mathrm{~min}$ in $\mathrm{I}=0$ mode, 6) measure $\mathrm{E}_{\mathrm{GABA}}$ in voltage-clamp mode, 7) glutamate exposure in $\mathrm{I}=0$ mode, 8) measure $\mathrm{E}_{\mathrm{GABA}}$ in voltage-clamp mode, 9) measure the input resistance in current-clamp mode, 10) measure APs for $1 \mathrm{~min}$ in $\mathrm{I}=0$ mode, 11) apply modulator for 2 min and measure APs during the last minute in $\mathrm{I}=0$ mode, 12) measure the input resistance in the continued presence of modulator in current-clamp mode, 13) washout modulator and allow the neurons to recover hyperpolarizing muscimol responses in $\mathrm{I}=0$ mode, 14$)$ measure $\mathrm{E}_{\mathrm{GABA}}$ in voltage-clamp mode, 15) measure APs for 1 min in $\mathrm{I}=0$ mode, 16) apply modulator for 2 min and measure APs during the last minute in $\mathrm{I}=0$ mode, 17) washout the modulator. The following sequence was performed for cells exposed to furosemide: 1) measure APs for 1 min in $\mathrm{I}=0$ mode, 2) apply modulator for $2 \mathrm{~min}$ and measure APs during the last minute in $\mathrm{I}=0$ mode, 3 ) washout modulator for $5 \mathrm{~min}$ in $\mathrm{I}=0$ mode, 4) measure $\mathrm{E}_{\mathrm{GABA}}$ in voltage-clamp mode, 5) furosemide exposure for $4 \mathrm{~min}$ in $\mathrm{I}=0$ mode, 6 ) measure $\mathrm{E}_{\mathrm{GABA}}$ in voltage-clamp mode in the continued presence of furosemide, 7) in the continued presence of furosemide measure APs for $1 \mathrm{~min}$ in $\mathrm{I}=0$ mode, 8$)$ in the continued presence of furosemide apply modulator for $2 \mathrm{~min}$ and measure APs during the last minute in $\mathrm{I}=0$ mode, 9 ) in the continued presence of furosemide washout modulator for $2 \mathrm{~min}, 10$ ) washout furosemide for $3 \mathrm{~min}, 11$ ) measure $\mathrm{E}_{\mathrm{GABA}}$ in voltage-clamp mode, 12) measure APs for $1 \mathrm{~min}$ in $\mathrm{I}=0$ mode, 13) apply modulator for 2 min and measure APs during the last minute in $\mathrm{I}=0$ mode, 14) washout the modulator.

\section{Statistical analysis}

All experimental data derived from experiments described here were analyzed as previously described (Lee et al., 2011). Statistical analysis was performed using GraphPad Prism 4 software (La Jolla, CA, USA). Paired t-tests (two-tailed) were used throughout except where indicated, and $P<0.05$ was considered significant. I-V relationships were fit by linear regression analysis using GraphPad. Action potentials were counted using Minianalysis software (Synaptosoft Inc., Decatur, GA, USA). The decay rates of GABAergic PSPs were analyzed in Clampfit using first order standard exponential fits with a Chebyshev search method. All data are reported as the mean \pm SEM.

\section{Results \\ Glutamate caused a positive shift in $\mathrm{E}_{\mathrm{GABA}}$ and reduced the inhibitory efficacy of diazepam}

Glutamate is a common pathophysiological factor involved in ischemia (Ginsberg, 2008) and seizures (During \& Spencer, 1993), that can also alter $\mathrm{Cl}^{-}$homeostasis and reduce KCC2 surface expression (Kitamura et al., 2008; Lee et al., 2011). We therefore utilized the 
glutamate model of hyperexcitability and perturbed $\mathrm{Cl}^{-}$homeostasis to test the hypothesis that the $\mathrm{Cl}^{-}$gradient is a significant determinant of the efficacy of diazepam. We began each experiment by demonstrating that test pulses with the selective $\mathrm{GABA}_{\mathrm{A}}$ agonist muscimol ( 5 $\mu \mathrm{M}-500 \mathrm{~ms}$, every $30 \mathrm{~s}$ ) hyperpolarized the membrane potential $\left(\mathrm{E}_{\mathrm{M}}\right)$, and that neurons exhibited GABAergic hyperpolarizing inhibitory postsynaptic potentials (IPSPs). In every neuron tested, we observed IPSPs that appeared alone and some that immediately followed action potentials (APs) or excitatory postsynaptic potentials (EPSPs) (Fig 1A), which together formed AP-IPSP or EPSP-IPSP sequences that are typical of disynaptic inhibitory microcircuits (Pavlov et al., 2011). These IPSPs that followed APs appeared as afterhyperpolarization components of the APs, but these were actually GABAergic as they were sensitive to diazepam and shifts in $\mathrm{E}_{\mathrm{GABA}}$ (discussed below). These observations indicated that neurons could cope with both the IPSP- and muscimol-induced $\mathrm{Cl}^{-}$loads, which is consistent with mature neurons expressing $\mathrm{KCC} 2$.

We then performed a specifically ordered sequence of electrophysiological protocols (see Methods). The resting membrane potential of these neurons was $-66 \pm 1 \mathrm{mV}(\mathrm{n}=10)$, indicating that the neurons were healthy. We then applied diazepam $(3 \mu \mathrm{M})$ to the bath solution for $2 \mathrm{~min}$ and measured its ability to inhibit APs during the last minute of exposure. Diazepam reduced the number of APs/min from $40 \pm 6$ prior to diazepam exposure, to $7 \pm 2$ APs/min during exposure $\left(\mathrm{n}=10, t_{9}=6.72, P<0.0001\right)$, which corresponded to a percent inhibition of $84 \pm 3 \%$ (Fig 1A,E). The percent inhibition, or inhibitory efficacy, was calculated for each neuron as the arithmetic difference between the number of APs/min prior to and during diazepam exposure divided by the number of APs/min prior to diazepam exposure. We then washed out diazepam for $5 \mathrm{~min}$ and measured the reversal potential of muscimol-activated currents (for consistency we will refer to this value as $\mathrm{E}_{\mathrm{GABA}}$ ) using voltage-ramp protocols (see Methods). The average basal $\mathrm{E}_{\mathrm{GABA}}$ value was $-83 \pm 2 \mathrm{mV}$ ( $\mathrm{n}$ $=10)$. We then calculated the driving force $\left(\mathrm{DF}_{\mathrm{GABA}}\right)$ on $\mathrm{GABA}_{\mathrm{A}}$-mediated currents ( $\mathrm{E}_{\mathrm{GABA}}-\mathrm{E}_{\mathrm{M}}$ ), which was $-17 \pm 2 \mathrm{mV}$ and gave rise to hyperpolarizing muscimol responses under basal conditions.

We determined that three $10 \mathrm{~s}$ pulses of glutamate $(20 \mu \mathrm{M})$ spaced $30 \mathrm{~s}$ apart caused a depolarizing muscimol response that was sustained for 5-10 min. This allowed us sufficient time to measure changes in $\mathrm{E}_{\mathrm{GABA}}$ and APs in the absence and then presence of diazepam while muscimol was still depolarizing (Fig 1B). Glutamate application quickly reversed the polarity of the muscimol responses and converted the GABAergic hyperpolarizing PSPs to depolarizing postsynaptic potentials (DPSPs). The AP-IPSP sequences were also transformed into AP-DPSP waveforms. Glutamate caused an average positive shift in $\mathrm{E}_{\mathrm{GABA}}$ to $-39 \pm 4 \mathrm{mV}\left(\mathrm{n}=10, t_{9}=7.75, P<0.0001\right)$ (Fig 1E). We also observed a postglutamate hyperpolarization to $-76 \pm 2 \mathrm{mV}$ (Thompson \& Prince, 1986), which contributed to $\mathrm{DF}_{\mathrm{GABA}}$ values of $+37 \pm 5 \mathrm{mV}(\mathrm{n}=10)$. As expected, glutamate exposure significantly increased the number of APs $/ \mathrm{min}$ from $40 \pm 6$ to $83 \pm 12\left(\mathrm{n}=10, t_{9}=2.90, P=0.0175\right)$. The subsequent application of diazepam caused a reduction in APs $/ \mathrm{min}$ to $36 \pm 7$ ( $t_{9}=4.91, P=$ 0.0008 ), corresponding to an inhibitory efficacy of only $57 \pm 6 \%$, which was significantly less than diazepam's efficacy measured prior to glutamate exposure $\left(\mathrm{n}=10, t_{9}=4.63, P=\right.$ 0.0012) (Fig 1C,E). These data indicated that brief exposure to glutamate reduced the inhibitory efficacy of diazepam by $32 \pm 7 \%$ (calculated as the percentage of 1 minus the ratio of the efficacy before and after glutamate).

For several neurons we then washed out diazepam and allowed the neurons to recover hyperpolarizing muscimol responses, which indicated that the initial positive shift in $\mathrm{E}_{\mathrm{GABA}}$ was temporary and immediately began to dissipate upon termination of the glutamate pulses due to sufficient amounts of KCC2. These neurons recovered $\mathrm{E}_{\mathrm{GABA}}$ values of $-84 \pm 2 \mathrm{mV}$ $\left(\mathrm{n}=5, t_{4}=0.52, P=0.6306\right.$ relative to the basal values of these 5 neurons only) and $\mathrm{E}_{\mathrm{M}}$ 
values of $-65 \pm 2 \mathrm{mV}\left(\mathrm{n}=5, t_{4}=1.32, P=0.2583\right.$ relative to the basal values of these 5 neurons only), resulting in $\mathrm{DF}_{\mathrm{GABA}}$ values of $-19 \pm 4 \mathrm{mV}$ (Fig 1D,E). We then measured the inhibitory efficacy of diazepam a third time, which recovered to near basal values and were significantly greater than values obtained immediately after glutamate exposure $(95 \pm$ $3 \%, \mathrm{n}=5, t_{4}=2.01, P=0.1144$ relative to the basal values of these 5 neurons only; $t_{4}=$ $3.25, P=0.0313$ relative to the values just after glutamate exposure of these 5 neurons only) (Fig 1D,E). These data indicated that glutamate caused a loss of hyperpolarizing $\mathrm{GABA}_{\mathrm{A}^{-}}$ mediated currents, increased excitability and decreased the ability of diazepam to suppress APs.

The most direct way to collapse the $\mathrm{Cl}^{-}$gradient and examine its impact on diazepam's efficacy is to pharmacologically block KCC2 activity. We therefore used the KCC2 inhibitor furosemide on a separate set of neurons (see Methods). These neurons had resting membrane potential values of $-65.7 \pm 2.5 \mathrm{mV}(\mathrm{n}=9)$. Similar to our experiments above, under basal conditions diazepam reduced the number of APs/min from $64 \pm 28$ to $13 \pm 8$ (n $\left.=9, t_{8}=2.46, P=0.0393\right)$, which corresponded to an inhibitory efficacy of $86 \pm 5 \%$. Furosemide $(500 \mu \mathrm{M})$ application rapidly collapsed the muscimol response and caused a 7.1 \pm 2.6 fold increase of APs/min (64 \pm 28 APs/min before, $221 \pm 48$ APs/min during furosemide; $\left.t_{8}=4.15, P=0.0032, \mathrm{n}=9\right)(\mathrm{Fig} 2 \mathrm{~A})$. This indicated that $\mathrm{KCC} 2$ and $\mathrm{Cl}^{-}$ dependent inhibition together functioned as an endogenous break on runaway excitability in cultured neuron networks (Jarolimek et al., 1996). Furosemide also temporarily depolarized the membrane potential $\left(-58.2 \pm 1.8 \mathrm{mV}\right.$ measured $1 \mathrm{~min}$ after furosemide onset, $\mathrm{n}=9, t_{8}=$ $5.24, P=0.0008$ compared to basal), so we waited for the membrane potential to return to basal values before proceeding $(-66.2 \pm 2.7 \mathrm{mV}$ measured 4 min after furosemide onset, $\mathrm{n}=$ $9, t_{8}=0.23, P=0.8226$ compared to basal). We then applied diazepam in the continued presence of furosemide, which reduced the number of APs/min from $221 \pm 48$ to $98 \pm 25$ (n $=9, t_{8}=4.43, P=0.0022$ ), corresponding to an inhibitory efficacy of only $60 \pm 6 \%$, which was significantly less than diazepam's efficacy before furosemide exposure $\left(\mathrm{n}=9, t_{8}=4.79\right.$, $P=0.0014$ ) (Fig 2B,D). In four of these neurons we also measured $\mathrm{E}_{\mathrm{GABA}}$ values before and during furosemide exposure, and found that it shifted $\mathrm{E}_{\mathrm{GABA}}$ values from $-82 \pm 3 \mathrm{mV}$ to $-39 \pm 4 \mathrm{mV}\left(\mathrm{n}=4, t_{3}=6.94, P=0.0061\right)$, which corresponded to a $\mathrm{DF}_{\mathrm{GABA}}$ shift from -18 $\pm 4 \mathrm{mV}$ to $+26 \pm 5 \mathrm{mV}$ (Fig 2B,D). Furosemide's effect on diazepam was not due to direct inhibition of $\mathrm{GABA}_{\mathrm{A}}$ receptors (Korpi et al., 1995; Wafford et al., 1996), since the slope conductance of the muscimol-activated currents did not significantly change (slope before $10.4 \pm 2.1 \mathrm{nS}$, slope during $8.1 \pm 1.3 \mathrm{nS}, \mathrm{n}=9, t_{8}=1.72, P=0.1239$; these values include 5 data points obtained from voltage-ramps performed on a separate set of neurons in the absence and presence of furosemide that are discussed below). After washout of diazepam, we then washed out furosemide, which allowed a rapid recovery of hyperpolarizing muscimol responses and suppression of neuronal activity, further indication that furosemide was the cause of the increased excitability (Fig 2C). We further examined three neurons, which reestablished $\mathrm{E}_{\mathrm{GABA}}$ values of $-88 \pm 3 \mathrm{mV}\left(\mathrm{n}=3, t_{2}=0.57, P=0.6257\right.$ compared to the basal values of these 3 neurons only) and $\mathrm{E}_{\mathrm{M}}$ values of $-58 \pm 2 \mathrm{mV}\left(\mathrm{n}=3, t_{2}=1.53, P=\right.$ 0.2664 compared to the basal values of these 3 neurons only), resulting in DFGABA values of $-30 \pm 4 \mathrm{mV}$ (Fig 2D). A third application of diazepam reduced the APs/min from $31 \pm 4$ to $5 \pm 4\left(\mathrm{n}=3, t_{2}=7.21, P=0.0187\right)$. This corresponded to an inhibitory efficacy of $85 \pm 10$ $\%$, which was similar to diazepam's efficacy prior to furosemide exposure on these three neurons $\left(t_{2}=1.44, P=0.2863\right)$, and significantly greater than diazepam's efficacy in the presence of furosemide on these neurons $\left(\mathrm{n}=3, t_{2}=7.98, P=0.0153\right)$ (Fig 2D). These data indicated that the effects of furosemide on diazepam's efficacy were not due to direct inhibition of certain types of $\mathrm{GABA}_{\mathrm{A}}$ receptors, and that changes in its inhibitory efficacy correlated with shifts in $\mathrm{E}_{\mathrm{GABA}}$ values. 
The concentration of furosemide used here is predicted to be sufficient for inhibition of the type $1 \mathrm{Na}^{+} / \mathrm{K}^{+} / \mathrm{Cl}^{-}$cotransporter (NKCC1) (Somasekharan et al., 2012). We therefore examined diazepam's inhibitory efficacy in the presence of the NKCC1 inhibitor bumetanide on a separate set of neurons (Payne, 1997; Haas \& Forbush, 1998). These neurons had resting membrane potential values of $-64 \pm 4 \mathrm{mV}(\mathrm{n}=6)$, indicating that they were healthy. A 6 min application of bumetanide $(10 \mu \mathrm{M})$, which is not predicted to significantly inhibit $\mathrm{KCC} 2$ function, did not shift $\mathrm{E}_{\mathrm{GABA}}$ values $(-94 \pm 4 \mathrm{mV}$ before and $-93 \pm 4 \mathrm{mV}$ during, $\left.\mathrm{n}=6, t_{5}=0.46, P=0.6646\right)$. Under basal conditions on this set of neurons, diazepam reduced the number of APs from $24 \pm 5$ to $7 \pm 2\left(\mathrm{n}=6, t_{5}=4.74, P=\right.$ 0.0052 ), corresponding to an inhibitory efficacy of $72 \pm 1 \%$. Whereas in the presence of bumetanide, diazepam reduced the number of APs from $16 \pm 4$ to $5 \pm 1\left(\mathrm{n}=6, t_{5}=3.73, P=\right.$ 0.0136 ), corresponding to an inhibitory efficacy of $72 \pm 8 \%$, which was not significantly different compared to the basal level $\left(t_{5}=0.02, P=0.9831\right)$. These data indicated that inhibition of NKCC1 did not contribute to the effects of furosemide.

Both glutamate and furosemide increased action potential frequency, so it is plausible that the reduced efficacy of diazepam was due to the increased number of APs, or conversely, that increases in action potential frequency collapse hyperpolarizing muscimol responses. We therefore used brief applications of the muscarinic receptor agonist carbachol $(20 \mu \mathrm{M}$, 2-6 min) to increase excitability without altering $\mathrm{E}_{\mathrm{GABA}}$. We examined the effects of carbachol on a separate set of neurons, which exhibited resting membrane potential values of $-62 \pm 2 \mathrm{mV}(\mathrm{n}=10)$. Under basal conditions, diazepam reduced the APs/min from $33 \pm 8$ to $6 \pm 1\left(\mathrm{n}=10, t_{9}=3.72, P=0.0048\right)$, corresponding to an inhibitory efficacy of $80 \pm 5 \%$ (Fig 3A,C). After washout of diazepam for $5 \mathrm{~min}$, we then applied carbachol, which did not collapse the amplitudes of the hyperpolarizing muscimol responses in any of the neurons tested (Fig 3B). In a subset of these neurons, we found that carbachol did not significantly shift $\mathrm{E}_{\mathrm{GABA}}$ values ( $-85 \pm 7 \mathrm{mV}$ before, $-77 \pm 6 \mathrm{mV}$ during, $\mathrm{n}=6, t_{5}=2.07, P=0.0932$ ) (Fig 3C), which agrees with recent observations in hippocampal slices that brief applications of carbachol did not affect $\mathrm{E}_{\mathrm{GABA}}$ (Takkala \& Woodin, 2013). Carbachol did increase the number of APs/min by $4.5 \pm 1.4$ fold (from $33 \pm 8$ to $134 \pm 35, \mathrm{n}=10, t_{9}=3.34, P=$ 0.0086) (Fig 3C). But in the continued presence of carbachol, diazepam reduced the number of APs/min to $37 \pm 11\left(\mathrm{n}=10, t_{9}=3.74, P=0.0047\right)$, corresponding to an inhibitory efficacy of $80 \pm 5 \%$, which was not statistically different from the basal efficacy $\left(\mathrm{n}=10, t_{9}=0.04, P\right.$ $=0.9723)($ Fig 3B,C). Overall, these data demonstrated that glutamate and furosemide rapidly collapsed the hyperpolarizing muscimol responses and reduced the inhibitory efficacy of diazepam, neither of which was due to increased firing rates.

\section{Glutamate did not reduce the number of $\mathrm{GABA}_{A}$ receptors or the modulatory efficacy of diazepam}

Several studies have demonstrated that glutamate can increase the lateral mobility of $\mathrm{GABA}_{\mathrm{A}}$ receptors (Muir et al., 2010; Niwa et al., 2012), a process that could increase the probability of receptor internalization (Smith et al., 2012). We therefore analyzed our voltage-ramp data to determine if glutamate altered the slope conductance of the muscimolactivated currents. The leak subtracted muscimol-activated currents had slope conductance values of $8.5 \pm 2.1 \mathrm{nS}$ before glutamate exposure and $7.2 \pm 2.1 \mathrm{nS}$ after glutamate exposure (n $\left.=10, t_{9}=1.55, P=0.1556\right)$. This indicated that glutamate did not significantly reduce the number of $\mathrm{GABA}_{\mathrm{A}}$ receptors mediating the muscimol-activated currents.

In our experiments, diazepam slowed the decay rates of the GABAergic hyperpolarizing and depolarizing PSPs. We therefore analyzed if diazepam prolonged the decay of DPSPs by the same amount as it did for IPSPs. Our experiments were conducted in the perforated patch configuration, which will overestimate the actual decay rate of the GABAergic postsynaptic potential; however, this does not preclude the measurement of diazepam's prolongation of 
the observed decay rates. We averaged the decay rates of 20 IPSPs in the absence and then 20 IPSPs in the presence of diazepam before glutamate exposure, and 20 DPSPs in the absence and then 20 DPSPs in the presence of diazepam after glutamate exposure on the same neurons $(\mathrm{n}=8)$. Diazepam application slowed the decay of IPSPs from $90 \pm 10 \mathrm{~ms}$ to $196 \pm 32 \mathrm{~ms}$ ( $\mathrm{n}=8$ neurons, $\left.t_{7}=4.46, P=0.0029\right)$, corresponding to a $213 \pm 16 \%$ increase (Fig 4A,C). After the glutamate exposure, diazepam prolonged the decay of DPSPs from $163 \pm 19 \mathrm{~ms}$ to $340 \pm 39 \mathrm{~ms}$ ( $\mathrm{n}=8$ neurons, $t_{7}=7.73, P=0.0001$ ), corresponding to a $211 \pm$ $10 \%$ increase (Fig 4B,C). The percent increase of the decay of GABAergic PSPs in both instances were statistically similar $\left(t_{14}=0.13, P=0.9010\right.$, two-tailed unpaired t-test).

The prolongation of the DPSPs by diazepam caused a biphasic waveform: a fast component that was diazepam-insensitive, and a slower component that was diazepam-sensitive (Fig 4B). We therefore examined if the fast component was actually a superimposed EPSP. Indeed, application of the ionotropic glutamate receptor antagonists DNQX $(20 \mu \mathrm{M})$ and AP5 $(50 \mu \mathrm{M})$ abolished the diazepam-insensitive fast component and isolated the true GABAergic DPSP (Fig 4D). We therefore ignored the fast component when fitting the DPSPs in the absence of the glutamatergic antagonists. The fits to the slow component of the diazepam-potentiated DPSP were similar in the absence and presence of the glutamatergic inhibitors, which validates ignoring the fast component (Fig 4E). These data indicated that the glutamate-induced reduction in the inhibitory efficacy of diazepam was not due to a loss of $\mathrm{GABA}_{\mathrm{A}}$ receptors or impaired modulation of the GABAergic PSPs.

\section{The glutamate-induced reduction of diazepam's inhibitory efficacy was due to $\mathrm{Cl}^{-}$ plasticity}

We attempted to limit the amount of $\mathrm{Cl}^{-}$loading during the glutamate pulse to demonstrate that the reduction of diazepam's efficacy was due to perturbed $\mathrm{Cl}^{-}$homeostasis. We conducted these experiments on a separate group of interleaved neurons and used the same exact sequence of protocols as we did for the glutamate experiments above (see Methods), although here we did not measure input resistance values after glutamate exposure. We previously demonstrated that GABAergic activity was a source of the glutamate-induced positive shift of $\mathrm{E}_{\mathrm{GABA}}$ (Deeb et al., 2011; Lee et al., 2011). However, we did not use glutamatergic antagonists and tetrodotoxin (TTX) in the current investigation, which permitted a rapid $\mathrm{E}_{\mathrm{GABA}}$ shift that was temporary. Examination of the depolarizing phase of the glutamate pulse revealed a high amount of hyperpolarizing GABAergic PSPs (Fig 5A) (Deeb et al., 2011). On this set of neurons, the inhibitory efficacy of diazepam was $81 \pm 7 \%$ under basal conditions ( $41 \pm 12 \mathrm{APs} / \mathrm{min}$ before to $8 \pm 3 \mathrm{APs} / \mathrm{min}$ during diazepam, $\mathrm{n}=5, t_{4}$ $=3.03, P=0.0389)$. We then exposed the neurons to glutamate, which increased the APs/ $\min$ from $41 \pm 12$ to $73 \pm 16\left(\mathrm{n}=5, t_{4}=4.74, P=0.0090\right)$. We measured $\mathrm{E}_{\mathrm{GABA}}$ values before and immediately after the glutamate exposure, which were shifted from $-81 \pm 4 \mathrm{mV}$ to $-44 \pm 5 \mathrm{mV}\left(\mathrm{n}=5, t_{4}=5.96, P=0.0040\right)$, and resulted in depolarizing muscimol responses that were sustained throughout the post-glutamate diazepam exposure as shown above (Fig 1C). We then applied diazepam exactly 2 minutes after the last glutamate pulse. After glutamate exposure diazepam reduced the number of APs/min from $73 \pm 16$ to $44 \pm 12$ $\left(\mathrm{n}=5, t_{4}=3.73, P=0.0203\right)$, which corresponded to an inhibitory efficacy of $43 \pm 9 \%$ that was significantly less than the basal values $\left(\mathrm{n}=5, t_{4}=5.35, P=0.0059\right)$.

In a parallel set of neurons, we measured the efficacy of diazepam before and after exposure to solutions containing glutamate, the $\mathrm{GABA}_{\mathrm{A}}$ receptor antagonist bicuculline $(50 \mu \mathrm{M})$, and the NKCC1 inhibitor bumetanide $(10 \mu \mathrm{M})$, which both contributed $\mathrm{Cl}^{-}$loads in our earlier investigation (Lee et al., 2011). This protocol allowed us to directly measure the impact of blocking the $\mathrm{Cl}^{-}$load on the efficacy of diazepam despite exposure to glutamate. Under basal conditions diazepam reduced the APs/min from $19 \pm 4$ to $4 \pm 1\left(\mathrm{n}=5, t_{4}=6.56, P=\right.$ 0.0028 ), which corresponded to a basal inhibitory efficacy of $84 \pm 5 \%$ (Fig 5C,E). After 
washout of diazepam for $5 \mathrm{~min}$ and the measurement of the basal $\mathrm{E}_{\mathrm{GABA}}$ value, we then applied the mixture of glutamate, bicuculline and bumetanide, which clearly blocked GABAergic activity during the glutamate pulse (Fig 5B). The combination of bicuculline and bumetanide limited the glutamate-induced $\mathrm{Cl}^{-}$load, resulting in an $\mathrm{E}_{\mathrm{GABA}}$ shift of only $16 \pm 4 \mathrm{mV}$, from $-86 \pm 5 \mathrm{mV}$ to $-70 \pm 2 \mathrm{mV}$ ( $\left.\mathrm{n}=5, t_{4}=4.41, P=0.0116\right)$ (Fig 5E). This indicated that $\mathrm{GABA}_{\mathrm{A}}$ receptors and $\mathrm{NKCC} 1$ were not the only mediators of the glutamateinduced $\mathrm{E}_{\mathrm{GABA}}$ shift (Slemmer et al., 2004). Nevertheless, all the neurons recovered hyperpolarizing muscimol responses during the post-glutamate diazepam exposure (Fig 5D). As stated above, we then applied diazepam 2 min after the last glutamate pulse. After exposure to glutamate, bicuculline and bumetanide, diazepam application reduced the number of APs $/ \mathrm{min}$ from $48 \pm 13$ to $9 \pm 4\left(\mathrm{n}=5, t_{4}=4.38, P=0.0119\right)$, corresponding to an inhibitory efficacy of $87 \pm 6 \%$, which was not statistically different from the basal values (n $=5, t_{4}=1.54, P=0.1979$ ) (Fig 5E). These data demonstrated that the glutamate-induced reduction of diazepam's efficacy was due to perturbed $\mathrm{Cl}^{-}$homeostasis and not due to other effects of glutamate on neuronal function.

\section{Propofol retained its inhibitory efficacy after glutamate treatment by reducing input resistance}

We then examined if glutamate exposure also affected the inhibitory efficacy of the intravenous anesthetic and $\mathrm{GABA}_{\mathrm{A}}$ modulator propofol (Hales and Lambert, 1991). These experiments were conducted in parallel with our glutamate-diazepam trials shown in Figure 1 and utilized the same procedures (see Methods). The resting membrane potential of these neurons was $-67 \pm 2 \mathrm{mV}(\mathrm{n}=15)$, indicating that these neurons were healthy. Propofol (1.5 $\mu \mathrm{M})$ reduced the number of APs $/$ min from $47 \pm 9$ to $1.4 \pm 0.6\left(\mathrm{n}=15, t_{14}=5.31, P=\right.$ 0.0001 ), corresponding to a basal inhibitory efficacy of $97 \pm 1 \%$ (Fig $6 \mathrm{~A}$ ). In contrast to diazepam, the glutamate exposure did not alter the inhibitory efficacy of propofol, it still reduced the number of APs $/ \mathrm{min}$ from $90 \pm 10$ to $8 \pm 5\left(\mathrm{n}=15, t_{14}=9.34, P<0.0001\right)$, which corresponded to an inhibitory efficacy of $94 \pm 3 \%$ that was not significantly different from basal values ( $\left.\mathrm{n}=15, t_{14}=1.05, P=0.3131\right)$ (Fig 6B,D). On a subset of these neurons, we also measured $\mathrm{E}_{\mathrm{GABA}}$ values before and just after glutamate exposure, which were shifted from $-82 \pm 3 \mathrm{mV}$ to $-48 \pm 5 \mathrm{mV}\left(\mathrm{n}=9, t_{8}=7.09, P=0.0001\right)$.

We also investigated the effects of furosemide on the inhibitory efficacy of propofol. These experiments were interleaved with the set of furosemide/diazepam experiments shown in Figure 2 and utilized the same protocols (see Methods). The resting membrane potential of these neurons was $-64 \pm 3 \mathrm{mV}(\mathrm{n}=8)$. Similar to the glutamate experiments, propofol reduced the number of APs $/ \mathrm{min}$ from $28 \pm 8$ to $1.4 \pm 0.4\left(\mathrm{n}=8, t_{7}=3.40, P=0.0115\right)$, corresponding to an inhibitory efficacy of $94 \pm 2 \%$. After six minutes, we then applied propofol for $2 \mathrm{~min}$ in the continued presence of furosemide. In sharp contrast to diazepam, furosemide did not significantly reduce the inhibitory efficacy of propofol (Fig 6C,D). It reduced the APs/min from $141 \pm 20$ to $19 \pm 6\left(\mathrm{n}=8, t_{7}=7.62, P=0.0001\right)$, corresponding to an inhibitory efficacy of $88 \pm 3 \%$, which was not statistically different from the basal values ( $\left.=8, t_{7}=1.47, P=0.1863\right)$. On a subset of these neurons, we waited 4 min after the onset of furosemide application before using voltage-ramp protocols to measure $\mathrm{E}_{\mathrm{GABA}}$ values, which were shifted from $-84 \pm 1 \mathrm{mV}$ to $-39 \pm 2 \mathrm{mV}\left(\mathrm{n}=5, t_{4}=19.63, P<0.0001\right)$. Thus, propofol's inhibitory efficacy was not reduced despite large positive shifts in $\mathrm{E}_{\mathrm{GABA}}$ values and depolarizing $\mathrm{GABA}_{\mathrm{A}}$-mediated currents.

Propofol caused a noticeable rapid hyperpolarization of the membrane potential under basal conditions $\left(-4.3 \pm 0.4 \mathrm{mV}, \mathrm{n}=15, t_{14}=10.28, P<0.0001\right)$, but we did not observe this during diazepam application $\left(+0.4 \pm 0.2 \mathrm{mV}, \mathrm{n}=10, t_{9}=2.17, P=0.0584\right)($ Fig $7 \mathrm{~A})$. We therefore tested if changes in input resistance could explain how propofol retained its inhibitory efficacy despite the glutamate-induced positive shift in $\mathrm{E}_{\mathrm{GABA}}$ values. These data 
were obtained from subsets of neurons presented in Figure 1 for the diazepam treatment, and Figure 6 for the propofol treatment. Prior to glutamate exposure, diazepam did not significantly affect the input resistance values, from $240 \pm 50 \mathrm{M} \Omega$ in the absence to $269 \pm 57$ $\mathrm{M} \Omega$ in the presence of diazepam ( $\mathrm{n}=8, t_{7}=1.60, P=0.1533$ ), which corresponded to an 11 $\pm 6 \%$ shift (Fig 7B,D). Diazepam also did not significantly affect the input resistance after exposure to glutamate, from $246 \pm 57 \mathrm{M} \Omega$ in the absence to $244 \pm 51 \mathrm{M} \Omega$ in the presence of diazepam ( $\mathrm{n}=8, t_{7}=0.15, P=0.8874$ ), which corresponded to a $5 \pm 6 \%$ shift. In contrast, propofol significantly reduced the input resistance both before and after exposure to glutamate (Fig 7C,E). Propofol reduced input resistance from $355 \pm 58 \mathrm{M} \Omega$ to $292 \pm 42 \mathrm{M} \Omega$ $\left(\mathrm{n}=9, t_{8}=2.53, P=0.0352\right)$, which corresponded to a $15 \pm 5 \%$ reduction when muscimol was hyperpolarizing. After exposure to glutamate and when muscimol was depolarizing, propofol still reduced the input resistance from $335 \pm 46 \mathrm{M} \Omega$ to $266 \pm 45 \mathrm{M} \Omega\left(\mathrm{n}=9, t_{8}=\right.$ $3.47, P=0.0084)$, which corresponded to a $21 \pm 6 \%$ reduction. These data demonstrated that the mechanism by which propofol retained its inhibitory efficacy was by reducing input resistance despite the loss of hyperpolarizing $\mathrm{GABA}_{\mathrm{A}}$-mediated currents.

\section{Discussion}

This is the first investigation to demonstrate that altered $\mathrm{Cl}^{-}$homeostasis reduces the inhibitory efficacy of diazepam on intact neurons. Furosemide and the common pathophysiological factor glutamate both reduced diazepam's inhibitory efficacy. These effects were not due to reductions in $\mathrm{GABA}_{\mathrm{A}}$ receptor number. Importantly, perturbed $\mathrm{Cl}^{-}$ homeostasis did not reduce the inhibitory efficacy of propofol. Our analysis revealed that propofol reduced input resistance even when muscimol was depolarizing, whereas diazepam did not significantly reduce input resistance. Our data indicate that the efficacy of diazepam is in part intrinsic to the neuronal $\mathrm{Cl}^{-}$gradient and is not necessarily dependent on glia or the architecture of inhibitory circuits.

Several investigations have highlighted the anticonvulsant effects of furosemide, but the effects are likely due to inhibition of glial NKCC1 and reductions in glial swelling (Hochman, 2012), or altered kidney function (Loscher et al., 2012). Our investigation supports the inhibitory role of $\mathrm{KCC} 2$-mediated $\mathrm{Cl}^{-}$extrusion in neurons (Jarolimek et al., 1996; Lewin et al., 2012). Furosemide increased network excitability by abolishing hyperpolarizing $\mathrm{GABA}_{\mathrm{A}}$ signaling and not by inhibiting $\mathrm{GABA}_{\mathrm{A}}$ receptors. Our data supports previous experiments on cultured neurons that demonstrated furosemide did not affect $\mathrm{GABA}_{\mathrm{A}}$ slope conductance but did significantly increase synaptic excitability (Jarolimek et al., 1996). These data suggest that the anticonvulsant effects of furosemide are not caused by inhibition of KCC2. We previously demonstrated that furosemide collapsed hyperpolarizing responses mediated by $\mathrm{GABA}_{\mathrm{A}}$ receptors without affecting the membrane potential (Lee et al., 2011), however those experiments were performed in the presence of TTX, AP5 and DNQX. Thus in the current study, furosemide's effects on membrane potential were caused by increased network activity that was driven by intracellular $\mathrm{Cl}^{-}$ accumulation. Further support of the inhibitory role of $\mathrm{KCC} 2$ was provided by computational modeling of KCC2 function in neurons, which demonstrated that the partial or complete loss of KCC2 function caused a catastrophic failure of GABAergic inhibition (Doyon et al., 2011).

In contrast to the inhibitory role of $\mathrm{KCC} 2$ that we observed, under specific experimental conditions $\mathrm{KCC} 2$ can drive excitation: increased $\mathrm{KCC} 2$-mediated $\mathrm{K}-\mathrm{Cl}$ extrusion elevates extracellular $\mathrm{K}^{+}$, thereby transiently increasing neuronal excitability and synchrony. This effect is caused by a GABAergic $\mathrm{Cl}^{-}$load and is dependent on bicarbonate ion (Viitanen et al., 2010). However we performed our experiments in HEPES buffered saline, which quickly negates the influence of bicarbonate ion on $\mathrm{GABA}_{\mathrm{A}}$-mediated currents and on 
KCC2-mediated excitation (Ruusuvuori et al., 2004). Furthermore, we placed a large (0.7 $\mathrm{mm}$ ) perfusion pipette just above the patched neuron, thereby limiting large changes in the extracellular $\mathrm{K}^{+}$concentration due to increased $\mathrm{KCC} 2-$ mediated $\mathrm{K}^{+}$extrusion. Alternatively, $\mathrm{KCC} 2$ can mediate net uptake of $\mathrm{Cl}^{-}$due to high extracellular $\mathrm{K}^{+}$or exceedingly low intracellular $\mathrm{Cl}^{-}$(DeFazio et al., 2000). Our data indicate that, regardless of the source, any $\mathrm{Cl}^{-}$load should reduce the inhibitory efficacy of diazepam.

After glutamate exposure, diazepam slowed the decay rates of GABAergic DPSPs by the same amount as it modulated the IPSPs under basal conditions, indicating that the synaptic $\mathrm{GABA}_{\mathrm{A}}$ receptors retained their sensitivity to diazepam and did not diffuse out of the synapse. In single particle tracking experiments the lateral diffusion of $\mathrm{GABA}_{\mathrm{A}}$ receptors increases at the $10 \mathrm{~min}$ time-point after a 4 min exposure to glutamate (Muir et al., 2010), and a 30 min treatment with NMDA declusters synaptic receptors (Niwa et al., 2012). Considering that we utilized only three $10 \mathrm{~s}$ glutamate pulses spread over a total of $90 \mathrm{~s}$, it is unlikely that enough $\mathrm{GABA}_{\mathrm{A}}$ receptors diffused out of the synapse that could account for the reduction in diazepam's inhibitory efficacy. We also did not observe changes in the slope conductance values after glutamate exposure or in the presence of furosemide, which further indicated that there were no detectable reductions in the total number of surface $\mathrm{GABA}_{\mathrm{A}}$ receptors in these experimental conditions.

The application of diazepam alone did not hyperpolarize the membrane potential or affect input resistance, indicating that in our experiments diazepam could only affect the membrane conductance in the presence of synaptically released GABA. Therefore, diazepam caused inhibition by two modes: by prolonging the duration of the hyperpolarizing PSP thereby reducing the probability of reaching action potential threshold, and/or by prolonging the duration of the postsynaptic $\mathrm{GABA}_{\mathrm{A}}$-mediated currents thereby increasing the probability of shunting the EPSPs. This interpretation is supported by data obtained in hippocampal slices from seizing and non-seizing rats: depolarizing GABAergic PSPs prevented action potential generation only if the incoming EPSP occurred when the postsynaptic $\mathrm{GABA}_{\mathrm{A}}$ receptors were in the conducting state (Pathak et al., 2007). In our experiments, glutamate caused positive shifts in $\mathrm{E}_{\mathrm{GABA}}$ thereby removing the hyperpolarizing mode of diazepam-induced inhibition and reducing the inhibitory efficacy of diazepam by $\sim 30 \%$. This indicated that diazepam's primary mode of inhibition was by shunting inhibition, which allowed diazepam to retain $\sim 70 \%$ of its inhibitory efficacy even when GABA was depolarizing. Further reductions in the inhibitory efficacy of diazepam can occur if there is a reduction in the number of $\mathrm{GABA}_{\mathrm{A}}$ receptors leading to a decrease in $\mathrm{GABA}_{\mathrm{A}}$ conductance (Bannai et al., 2009), or by raising the $\mathrm{E}_{\mathrm{GABA}}$ value beyond action potential threshold resulting in direct excitatory effects of GABA (Lee et al., 2011). Indeed, high intracellular $\mathrm{Cl}^{-}$resulted in excitatory GABA and converted the efficacy of the benzodiazepine flunitrazepam and the barbiturate pentobarbital from inhibitory to excitatory on CA1 neurons in hippocampal slices (Staley, 1992). Even though the whole-cell patch clamp technique was used throughout, to the best of our knowledge this is the only study that has examined any correlation between the inhibitory efficacy of $\mathrm{GABA}_{\mathrm{A}}$ modulators and intracellular $\mathrm{Cl}^{-}$concentration. Therefore, our study is the first to demonstrate that positive shifts in $\mathrm{E}_{\mathrm{GABA}}$ can reduce the inhibitory efficacy of a benzodiazepine without causing it to become excitatory.

Alternatively, our experiments demonstrated that propofol directly shunted the membrane conductance even when $\mathrm{GABA}_{\mathrm{A}}$ receptors depolarized the neurons. Benzodiazepines such as flunitrazepam and diazepam potentiate GABA-activated currents but do not directly activate a large portion of the receptors on the membrane (Farrant \& Nusser, 2005).

Although they do not bind to the same allosteric sites on $\mathrm{GABA}_{\mathrm{A}}$ receptors (Bali \& Akabas, 2004; Mercado \& Czajkowski, 2008), the anesthetic pentobarbital shares an important 
property with the anesthetic propofol: high concentrations of the anesthetics can directly activate a large portion of the receptors to generate a low amplitude $\mathrm{Cl}^{-}$current (Thompson et al., 1996; Wafford et al., 1996). This is a key pharmacological effect that distinguishes the GABAergic anesthetics from the typical benzodiazepines such as diazepam. However, we applied concentrations of propofol that are well below the $\mathrm{EC}_{50}$ for direct activation of a $1 \beta 2 \gamma 2 \mathrm{GABA}_{\mathrm{A}}$ receptors (Feng \& Macdonald, 2004; Hales et al., 2006). But our data is supported by previous experiments on cultured hippocampal neurons that demonstrated that low concentrations of propofol can activate a tonic conductance (Bai et al., 2001). To date, the efficacy and potency of direct activation by propofol has not been investigated for most $\mathrm{GABA}_{\mathrm{A}}$ receptor subtypes.

Glutamate is a known pathophysiological factor in several neurological disorders. $\mathrm{GABA}_{\mathrm{A}}$ modulators have been tested as therapies in animal models of ischemia and humans after stroke (Ginsberg, 2008). Interestingly, the enhancement of $\mathrm{GABA}_{\mathrm{A}}$ activity loses therapeutic efficacy at later times of treatment (Sydserff et al., 1995), whereas the reduction of $\mathrm{GABA}_{\mathrm{A}}$ activity improves outcomes at later times of treatment in a rodent model of ischemia (Clarkson et al., 2010). Excessive glutamate release also has deleterious effects during seizures. Microdialysis measurements in conscious humans revealed that ambient glutamate surges into the micromolar range prior to, during and after a seizure (During \& Spencer, 1993), as well as in several rat models of chemical-induced seizures (Lallement et al., 1991; Liu et al., 1997; Ueda et al., 2002). Interestingly, rats undergoing pilocarpineinduced SE develop resistance to diazepam with increasing durations of seizures (Morrisett et al., 1987; Walton \& Treiman, 1988; Rice \& DeLorenzo, 1999; Jones et al., 2002). In this model, the efficacy of diazepam decreases by an order of magnitude within $10 \mathrm{~min}$ of the first stage three seizure, which is similar to the temporal development of diazepam resistance in human patients undergoing SE (Mayer et al. 2002; Treiman et al. 1998). Although not investigated directly in these particular studies, the release of glutamate correlates with the onset of diazepam-resistance during SE. It is therefore possible that surges of glutamate during the initial stages of $\mathrm{SE}$ cause $\mathrm{Cl}^{-}$loading that underlies the reduction in the therapeutic efficacy of diazepam, but as our data indicates, this would not significantly reduce the efficacy of propofol, which is an often used and reliable treatment for diazepam-resistant SE (Garcia Penas et al., 2007; Shorvon \& Ferlisi, 2012). Thus, our data indicates that perturbed $\mathrm{Cl}^{-}$homeostasis as a hypothetical underlying mechanism of diazepam-resistance during SE should not be ruled out simply because a different GABA $A$ modulator, propofol, retains its efficacy.

While it is evident in animal models of several human diseases that $\mathrm{KCC} 2$ functional expression is altered, it remains unclear how these changes determine the development and maintenance of pathophysiological states. It is also unknown if these deficits in KCC2 have direct impacts on the efficacy of $\mathrm{GABA}_{\mathrm{A}}$ and glycine receptor modulators in vivo. However, our investigation has revealed a significant and rapid impact of impaired KCC2 activity and perturbed $\mathrm{Cl}^{-}$homeostasis on the efficacy of diazepam. Our experiments also suggest that increasing $\mathrm{KCC} 2$ activity could maintain or restore the therapeutic effectiveness of $\mathrm{GABA}_{\mathrm{A}}$ modulators by limiting intracellular $\mathrm{Cl}^{-}$accumulation. Further research will undoubtedly shed more light on the impact of $\mathrm{Cl}^{-}$homeostasis on GABAergic and glycinergic signaling as well as the therapeutic reagents that target these neurotransmitter systems.

\section{Acknowledgments}

SJM is supported by NIH-NINDS grants, NS051195, NS056359, NS081735, NIH-NIMH grant, MH097446, CURE and the Simons Foundation. SJM serves as a consultant for SAGE therapeutics and Astrazeneca, relationships that are regulated by Tufts University and do not impact on this study. PAD is supported by NIH-NIAAA grant, AA017938 and NIH-NIMH grant, MH097446. 


\section{Abbreviations}

$\begin{array}{ll}\text { APs } & \text { action potentials } \\ \text { DPSPs } & \text { depolarizing postsynaptic potentials } \\ \text { EC }_{\mathbf{5 0}} & 50 \% \text { effective concentration } \\ \text { E }_{\text {GABA }} & \text { reversal potential of } \mathrm{GABA}_{\mathrm{A}} \text {-mediated currents } \\ \mathbf{E}_{\mathbf{M}} & \text { membrane potential } \\ \text { EPSPs } & \text { excitatory postsynaptic potentials } \\ \text { GABA } & \gamma \text {-amino butyric acid } \\ \text { GABA } & \gamma \text {-amino butyric acid type A receptor } \\ \text { IPSPs } & \text { inhibitory postsynaptic potentials } \\ \text { KCC2 } & \mathrm{K}^{+}-\mathrm{Cl}^{-} \text {cotransporter type } 2 \\ \text { SE } & \text { status epilepticus } \\ \text { NMDA } & \mathrm{N} \text {-methyl-D-aspartate }^{-} \\ \text {NKCC1 } & \mathrm{Na}^{+} / \mathrm{K}^{+} / \mathrm{Cl}^{-} \text {cotransporter type } 1 \\ \text { PSPs } & \text { postsynaptic potentials } \\ \text { TTX } & \text { tetrodotoxin }\end{array}$

\section{References}

Bai D, Zhu G, Pennefather P, Jackson MF, MacDonald JF, Orser BA. Distinct functional and pharmacological properties of tonic and quantal inhibitory postsynaptic currents mediated by gamma-aminobutyric acid(A) receptors in hippocampal neurons. Mol Pharmacol. 2001; 59:814824. [PubMed: 11259626]

Bali M, Akabas MH. Defining the propofol binding site location on the GABAA receptor. Mol Pharmacol. 2004; 65:68-76. [PubMed: 14722238]

Bannai H, Levi S, Schweizer C, Inoue T, Launey T, Racine V, Sibarita JB, Mikoshiba K, Triller A. Activity-dependent tuning of inhibitory neurotransmission based on GABAAR diffusion dynamics. Neuron. 2009; 62:670-682. [PubMed: 19524526]

Blaesse P, Airaksinen MS, Rivera C, Kaila K. Cation-chloride cotransporters and neuronal function. Neuron. 2009; 61:820-838. [PubMed: 19323993]

Brooks-Kayal AR, Shumate MD, Jin H, Rikhter TY, Coulter DA. Selective changes in single cell GABA(A) receptor subunit expression and function in temporal lobe epilepsy. Nat Med. 1998; 4:1166-1172. [PubMed: 9771750]

Clarkson AN, Huang BS, Macisaac SE, Mody I, Carmichael ST. Reducing excessive GABA-mediated tonic inhibition promotes functional recovery after stroke. Nature. 2010; 468:305-309. [PubMed: 21048709]

Coull JA, Boudreau D, Bachand K, Prescott SA, Nault F, Sik A, De Koninck P, De Koninck Y. Transsynaptic shift in anion gradient in spinal lamina I neurons as a mechanism of neuropathic pain. Nature. 2003; 424:938-942. [PubMed: 12931188]

Deeb TZ, Lee HH, Walker JA, Davies PA, Moss SJ. Hyperpolarizing GABAergic transmission depends on KCC2 function and membrane potential. Channels (Austin). 2011; 5:475-481. [PubMed: 22082832]

DeFazio RA, Keros S, Quick MW, Hablitz JJ. Potassium-coupled chloride cotransport controls intracellular chloride in rat neocortical pyramidal neurons. J Neurosci. 2000; 20:8069-8076. [PubMed: 11050128] 
Doyon N, Prescott SA, Castonguay A, Godin AG, Kroger H, De Koninck Y. Efficacy of synaptic inhibition depends on multiple, dynamically interacting mechanisms implicated in chloride homeostasis. PLoS Comput Biol. 2011; 7:e1002149. [PubMed: 21931544]

During MJ, Spencer DD. Extracellular hippocampal glutamate and spontaneous seizure in the conscious human brain. Lancet. 1993; 341:1607-1610. [PubMed: 8099987]

Farrant M, Nusser Z. Variations on an inhibitory theme: phasic and tonic activation of GABA(A) receptors. Nat Rev Neurosci. 2005; 6:215-229. [PubMed: 15738957]

Feng HJ, Macdonald RL. Multiple actions of propofol on alphabetagamma and alphabetadelta GABAA receptors. Mol Pharmacol. 2004; 66:1517-1524. [PubMed: 15331770]

Fujiwara-Tsukamoto Y, Isomura Y, Imanishi M, Ninomiya T, Tsukada M, Yanagawa Y, Fukai T, Takada M. Prototypic Seizure Activity Driven by Mature Hippocampal Fast-Spiking Interneurons. J Neurosci. 2010; 30:13679-13689. [PubMed: 20943908]

Galeffi F, Sah R, Pond BB, George A, Schwartz-Bloom RD. Changes in intracellular chloride after oxygen-glucose deprivation of the adult hippocampal slice: effect of diazepam. J Neurosci. 2004; 24:4478-4488. [PubMed: 15128862]

Garcia Penas JJ, Molins A, Salas Puig J. Status epilepticus: evidence and controversy. Neurologist. 2007; 13:S62-73. [PubMed: 18090953]

Ginsberg MD. Neuroprotection for ischemic stroke: past, present and future. Neuropharmacology. 2008; 55:363-389. [PubMed: 18308347]

Goodkin HP, Joshi S, Mtchedlishvili Z, Brar J, Kapur J. Subunit-specific trafficking of GABA(A) receptors during status epilepticus. J Neurosci. 2008; 28:2527-2538. [PubMed: 18322097]

Goodkin HP, Kapur J. The impact of diazepam's discovery on the treatment and understanding of status epilepticus. Epilepsia. 2009; 50:2011-2018. [PubMed: 19674049]

Goodkin HP, Yeh JL, Kapur J. Status epilepticus increases the intracellular accumulation of GABAA receptors. J Neurosci. 2005; 25:5511-5520. [PubMed: 15944379]

Haas M, Forbush B 3rd. The Na-K-Cl cotransporters. J Bioenerg Biomembr. 1998; 30:161-172. [PubMed: 9672238]

Hales TG, Deeb TZ, Tang H, Bollan KA, King DP, Johnson SJ, Connolly CN. An asymmetric contribution to gamma-aminobutyric type A receptor function of a conserved lysine within TM2-3 of alpha1, beta2, and gamma2 subunits. J Biol Chem. 2006; 281:17034-17043. [PubMed: 16627470]

Hochman DW. The extracellular space and epileptic activity in the adult brain: explaining the antiepileptic effects of furosemide and bumetanide. Epilepsia. 2012; 53(Suppl 1):18-25. [PubMed: 22612805]

Huberfeld G, Wittner L, Clemenceau S, Baulac M, Kaila K, Miles R, Rivera C. Perturbed chloride homeostasis and GABAergic signaling in human temporal lobe epilepsy. J Neurosci. 2007; 27:9866-9873. [PubMed: 17855601]

Jaenisch N, Witte OW, Frahm C. Downregulation of potassium chloride cotransporter KCC2 after transient focal cerebral ischemia. Stroke. 2010; 41:e151-159. [PubMed: 20044519]

Jarolimek W, Brunner H, Lewen A, Misgeld U. Role of chloride-homeostasis in the inhibitory control of neuronal network oscillators. J Neurophysiol. 1996; 75:2654-2657. [PubMed: 8793770]

Jones DM, Esmaeil N, Maren S, Macdonald RL. Characterization of pharmacoresistance to benzodiazepines in the rat Li-pilocarpine model of status epilepticus. Epilepsy Res. 2002; 50:301312. [PubMed: 12200221]

Kitamura A, Ishibashi H, Watanabe M, Takatsuru Y, Brodwick M, Nabekura J. Sustained depolarizing shift of the GABA reversal potential by glutamate receptor activation in hippocampal neurons. Neurosci Res. 2008; 62:270-277. [PubMed: 18840481]

Korpi ER, Kuner T, Seeburg PH, Luddens H. Selective antagonist for the cerebellar granule cellspecific gamma-aminobutyric acid type A receptor. Mol Pharmacol. 1995; 47:283-289. [PubMed: 7870036]

Lallement G, Carpentier P, Collet A, Pernot-Marino I, Baubichon D, Blanchet G. Effects of somaninduced seizures on different extracellular amino acid levels and on glutamate uptake in rat hippocampus. Brain Res. 1991; 563:234-240. [PubMed: 1786536] 
Lee HH, Deeb TZ, Walker JA, Davies PA, Moss SJ. NMDA receptor activity downregulates KCC2 resulting in depolarizing GABAA receptor-mediated currents. Nat Neurosci. 2011; 14:736-743. [PubMed: 21532577]

Lewin N, Aksay E, Clancy CE. Computational modeling reveals dendritic origins of GABA(A)mediated excitation in CA1 pyramidal neurons. PLoS One. 2012; 7:e47250. [PubMed: 23071770]

Liu Z, Stafstrom CE, Sarkisian MR, Yang Y, Hori A, Tandon P, Holmes GL. Seizure-induced glutamate release in mature and immature animals: an in vivo microdialysis study. Neuroreport. 1997; 8:2019-2023. [PubMed: 9223095]

Loscher W, Puskarjov M, Kaila K. Cation-chloride cotransporters NKCC1 and KCC2 as potential targets for novel antiepileptic and antiepileptogenic treatments. Neuropharmacology. 2012

Loup F, Wieser HG, Yonekawa Y, Aguzzi A, Fritschy JM. Selective alterations in GABAA receptor subtypes in human temporal lobe epilepsy. J Neurosci. 2000; 20:5401-5419. [PubMed: 10884325]

Lu Y, Zheng J, Xiong L, Zimmermann M, Yang J. Spinal cord injury-induced attenuation of GABAergic inhibition in spinal dorsal horn circuits is associated with down-regulation of the chloride transporter KCC2 in rat. J Physiol. 2008; 586:5701-5715. [PubMed: 18845615]

Mercado J, Czajkowski C. Gamma-aminobutyric acid (GABA) and pentobarbital induce different conformational rearrangements in the GABA A receptor alpha1 and beta2 pre-M1 regions. J Biol Chem. 2008; 283:15250-15257. [PubMed: 18387955]

Mody I, Maguire J. The reciprocal regulation of stress hormones and GABA(A) receptors. Front Cell Neurosci. 2011; 6:4. [PubMed: 22319473]

Morrisett RA, Jope RS, Snead OC 3rd. Effects of drugs on the initiation and maintenance of status epilepticus induced by administration of pilocarpine to lithium-pretreated rats. Exp Neurol. 1987; 97:193-200. [PubMed: 3582562]

Muir J, Arancibia-Carcamo IL, MacAskill AF, Smith KR, Griffin LD, Kittler JT. NMDA receptors regulate GABAA receptor lateral mobility and clustering at inhibitory synapses through serine 327 on the gamma2 subunit. Proc Natl Acad Sci U S A. 2010; 107:16679-16684. [PubMed: 20823221]

Naylor DE, Liu H, Wasterlain CG. Trafficking of GABA(A) receptors, loss of inhibition, and a mechanism for pharmacoresistance in status epilepticus. J Neurosci. 2005; 25:7724-7733. [PubMed: 16120773]

Niwa F, Bannai H, Arizono M, Fukatsu K, Triller A, Mikoshiba K. Gephyrin-independent GABA(A)R mobility and clustering during plasticity. PLoS One. 2012; 7:e36148. [PubMed: 22563445]

Orser BA, Canning KJ, Macdonald JF. Mechanisms of general anesthesia. Curr Opin Anaesthesiol. 2002; 15:427-433. [PubMed: 17019234]

Papp E, Rivera C, Kaila K, Freund TF. Relationship between neuronal vulnerability and potassiumchloride cotransporter 2 immunoreactivity in hippocampus following transient forebrain ischemia. Neuroscience. 2008; 154:677-689. [PubMed: 18472345]

Pathak HR, Weissinger F, Terunuma M, Carlson GC, Hsu FC, Moss SJ, Coulter DA. Disrupted dentate granule cell chloride regulation enhances synaptic excitability during development of temporal lobe epilepsy. J Neurosci. 2007; 27:14012-14022. [PubMed: 18094240]

Pavlov I, Scimemi A, Savtchenko L, Kullmann DM, Walker MC. I(h)-mediated depolarization enhances the temporal precision of neuronal integration. Nat Commun. 2011; 2:199. [PubMed: 21326231]

Payne JA. Functional characterization of the neuronal-specific K-Cl cotransporter: implications for [K +]o regulation. Am J Physiol. 1997; 273:C1516-1525. [PubMed: 9374636]

Rice AC, DeLorenzo RJ. N-methyl-D-aspartate receptor activation regulates refractoriness of status epilepticus to diazepam. Neuroscience. 1999; 93:117-123. [PubMed: 10430476]

Rivera C, Voipio J, Kaila K. Two developmental switches in GABAergic signalling: the $\mathrm{K}+-\mathrm{Cl}-$ cotransporter KCC2 and carbonic anhydrase CAVII. J Physiol. 2005; 562:27-36. [PubMed: 15528236]

Rudolph U, Knoflach F. Beyond classical benzodiazepines: novel therapeutic potential of GABAA receptor subtypes. Nat Rev Drug Discov. 2011; 10:685-697. [PubMed: 21799515]

Ruusuvuori E, Li H, Huttu K, Palva JM, Smirnov S, Rivera C, Kaila K, Voipio J. Carbonic anhydrase isoform VII acts as a molecular switch in the development of synchronous gamma-frequency 
firing of hippocampal CA1 pyramidal cells. J Neurosci. 2004; 24:2699-2707. [PubMed: 15028762]

Saliba RS, Kretschmannova K, Moss SJ. Activity-dependent phosphorylation of GABAA receptors regulates receptor insertion and tonic current. EMBO J. 2012; 31:2937-2951. [PubMed: 22531784]

Shorvon S, Ferlisi M. The outcome of therapies in refractory and super-refractory convulsive status epilepticus and recommendations for therapy. Brain. 2012; 135:2314-2328. [PubMed: 22577217]

Slemmer JE, Matsushita S, De Zeeuw CI, Weber JT, Knopfel T. Glutamate-induced elevations in intracellular chloride concentration in hippocampal cell cultures derived from EYFP-expressing mice. Eur J Neurosci. 2004; 19:2915-2922. [PubMed: 15182298]

Smith KR, Muir J, Rao Y, Browarski M, Gruenig MC, Sheehan DF, Haucke V, Kittler JT. Stabilization of GABA(A) receptors at endocytic zones is mediated by an AP2 binding motif within the GABA(A) receptor beta3 subunit. J Neurosci. 2012; 32:2485-2498. [PubMed: 22396422]

Somasekharan S, Tanis J, Forbush B. Loop diuretic and ion-binding residues revealed by scanning mutagenesis of transmembrane helix 3 (TM3) of Na-K-Cl cotransporter (NKCC1). J Biol Chem. 2012; 287:17308-17317. [PubMed: 22437837]

Staley K. Enhancement of the excitatory actions of GABA by barbiturates and benzodiazepines. Neurosci Lett. 1992; 146:105-107. [PubMed: 1282225]

Sydserff SG, Cross AJ, Green AR. The neuroprotective effect of chlormethiazole on ischaemic neuronal damage following permanent middle cerebral artery ischaemia in the rat. Neurodegeneration. 1995; 4:323-328. [PubMed: 8581565]

Takkala P, Woodin MA. Muscarinic acetylcholine receptor activation prevents disinhibition-mediated LTP in the hippocampus. Front Cell Neurosci. 2013; 7:16. [PubMed: 23450426]

Terunuma M, Xu J, Vithlani M, Sieghart W, Kittler J, Pangalos M, Haydon PG, Coulter DA, Moss SJ. Deficits in phosphorylation of GABA(A) receptors by intimately associated protein kinase C activity underlie compromised synaptic inhibition during status epilepticus. J Neurosci. 2008; 28:376-384. [PubMed: 18184780]

Thompson SA, Whiting PJ, Wafford KA. Barbiturate interactions at the human GABAA receptor: dependence on receptor subunit combination. Br J Pharmacol. 1996; 117:521-527. [PubMed: 8821543]

Thompson SM, Gahwiler BH. Activity-dependent disinhibition. I. Repetitive stimulation reduces IPSP driving force and conductance in the hippocampus in vitro. J Neurophysiol. 1989a; 61:501-511. [PubMed: 2709096]

Thompson SM, Gahwiler BH. Activity-dependent disinhibition. II. Effects of extracellular potassium, furosemide, and membrane potential on ECl- in hippocampal CA3 neurons. J Neurophysiol. 1989b; 61:512-523. [PubMed: 2709097]

Thompson SM, Prince DA. Activation of electrogenic sodium pump in hippocampal CA1 neurons following glutamate-induced depolarization. J Neurophysiol. 1986; 56:507-522. [PubMed: 2428952]

Ueda Y, Yokoyama H, Nakajima A, Tokumaru J, Doi T, Mitsuyama Y. Glutamate excess and free radical formation during and following kainic acid-induced status epilepticus. Exp Brain Res. 2002; 147:219-226. [PubMed: 12410337]

Viitanen T, Ruusuvuori E, Kaila K, Voipio J. The K+-Cl cotransporter KCC2 promotes GABAergic excitation in the mature rat hippocampus. J Physiol. 2010; 588:1527-1540. [PubMed: 20211979]

Wafford KA, Thompson SA, Thomas D, Sikela J, Wilcox AS, Whiting PJ. Functional characterization of human gamma-aminobutyric acidA receptors containing the alpha 4 subunit. Mol Pharmacol. 1996; 50:670-678. [PubMed: 8794909]

Walton NY, Treiman DM. Response of status epilepticus induced by lithium and pilocarpine to treatment with diazepam. Exp Neurol. 1988; 101:267-275. [PubMed: 3396644]

Wu LA, Huang J, Wang W, Wang XJ, Wu SX. Down-regulation of K+-Cl-co-transporter 2 in mouse medullary dorsal horn contributes to the formalin-induced inflammatory orofacial pain. Neurosci Lett. 2009; 457:36-40. [PubMed: 19429157] 

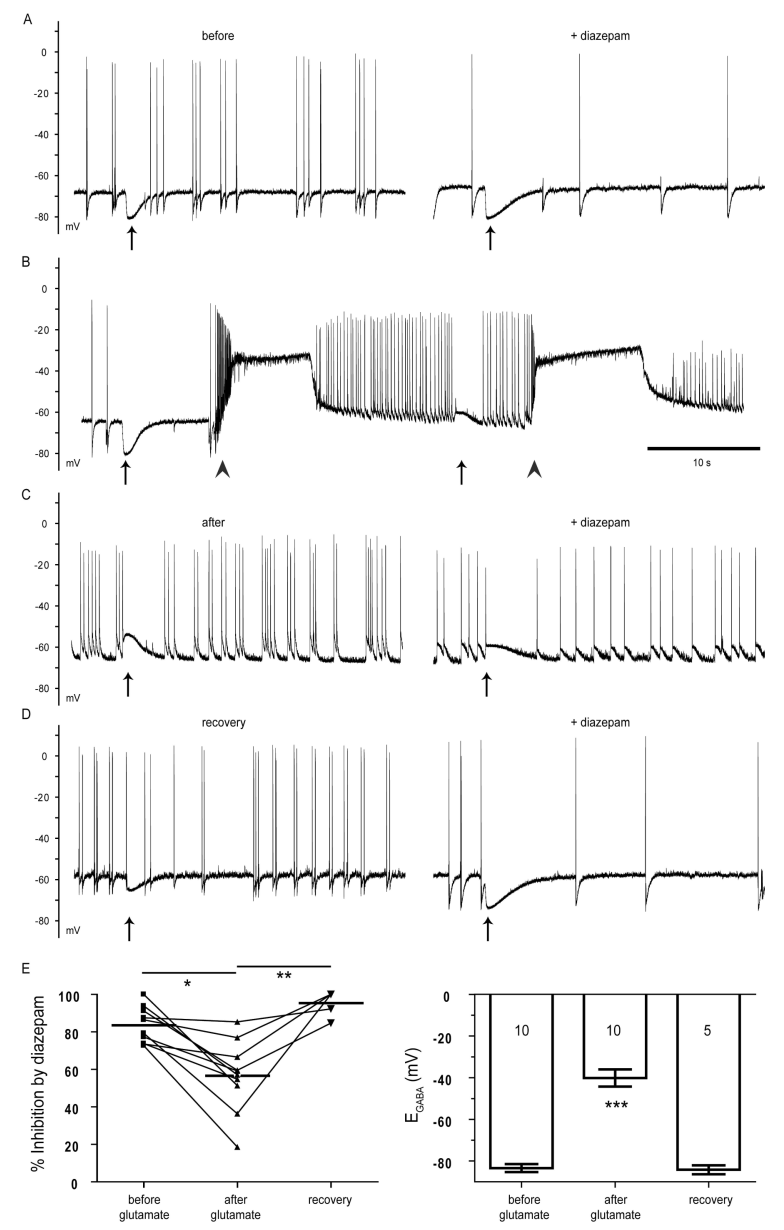

Figure 1.

Glutamate decreased the inhibitory efficacy of diazepam. (A) Basal activity (left) was strongly suppressed by diazepam (right). (B) Glutamate (arrowheads) caused a rapid depolarization of the membrane. Glutamate was applied in $10 \mathrm{~s}$ pulses spaced $30 \mathrm{~s}$ apart (only two of three pulses are shown), and muscimol tests pulses (arrows) were applied in between to indicate shifts in $\mathrm{E}_{\mathrm{GABA}}$. Glutamate exposure immediately shifted the muscimol responses from hyperpolarizing to depolarizing and increased the action potential frequency. (C) Two minutes after the last glutamate pulse, muscimol responses were still depolarizing (left), and diazepam caused a weak suppression of neuronal activity (right). (D) Upon recovery of hyperpolarizing muscimol responses (left), the inhibitory efficacy of diazepam returned to basal values (right). (E) Summary graphs depicting the changes in the efficacy of diazepam (left) and $\mathrm{E}_{\mathrm{GABA}}$ (right) before the glutamate exposure, just after the glutamate exposure, and once the neurons recovered hyperpolarizing muscimol responses. For the inhibitory efficacy plot, sticks connect data points for each cell, and the mean values are represented by horizontal lines. The $n$ numbers are indicated within the $\mathrm{E}_{\mathrm{GABA}}$ bars. * indicates statistical significance between values before and after glutamate exposure $(\mathrm{n}=10$, $\left.t_{9}=4.63, P=0.0012\right)$; ** indicates statistical significance between values obtained only for the 5 neurons examined just after glutamate exposure and after full recovery $\left(\mathrm{n}=5, t_{4}=\right.$ $3.25, P=0.0313)$; *** indicates statistical significance between values before and after glutamate exposure $\left(\mathrm{n}=10, t_{9}=7.75, P<0.0001\right)$. 


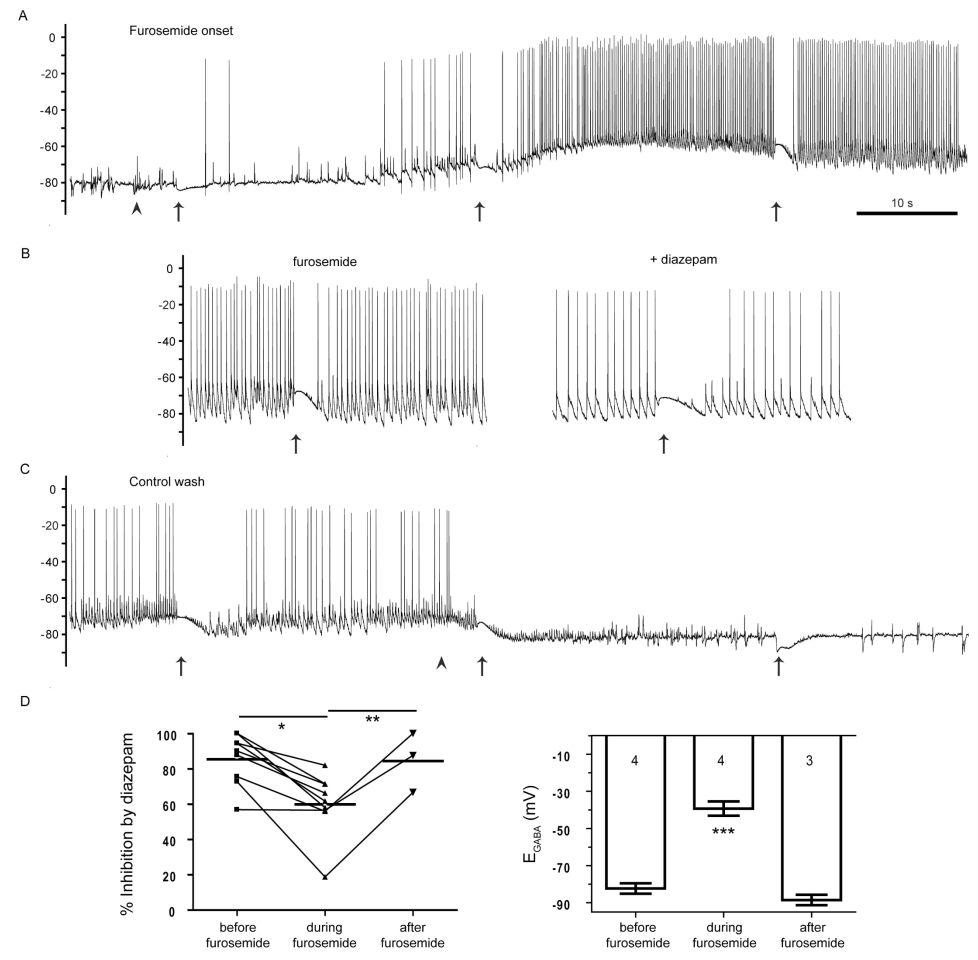

Figure 2.

Furosemide reduces the inhibitory efficacy of diazepam. (A) Furosemide (arrowhead) caused a rapid increase in action potentials and switched the muscimol responses (arrows) from hyperpolarizing to depolarizing. (B) Neurons exhibited stable depolarizing muscimol responses in the continued presence of furosemide $(6 \mathrm{~min})$ alone (left), and in the presence of diazepam (right). (C) Washout of furosemide (arrowhead) demonstrates the rapid recovery of hyperpolarizing muscimol responses and suppression of network activity. (D) Summary graphs depicting the changes in the efficacy of diazepam (left) and $\mathrm{E}_{\mathrm{GABA}}$ (right) before, during and after furosemide exposure. For the inhibitory efficacy plot, sticks connect data points for each cell, and the mean values are represented by horizontal lines. The $\mathrm{n}$ numbers are indicated within the $\mathrm{E}_{\mathrm{GABA}}$ bars. * indicates statistical significance between values before and during furosemide exposure $\left(\mathrm{n}=9, t_{8}=4.79, P=0.0014\right)$; ** indicates statistical significance between values obtained only on the three neurons that were examined during and after furosemide exposure $\left(\mathrm{n}=3, t_{2}=7.98, P=0.0153\right)$; *** indicates statistical significance between values before and during furosemide exposure $\left(\mathrm{n}=4, t_{3}=\right.$ 6.94, $P=0.0061)$. 

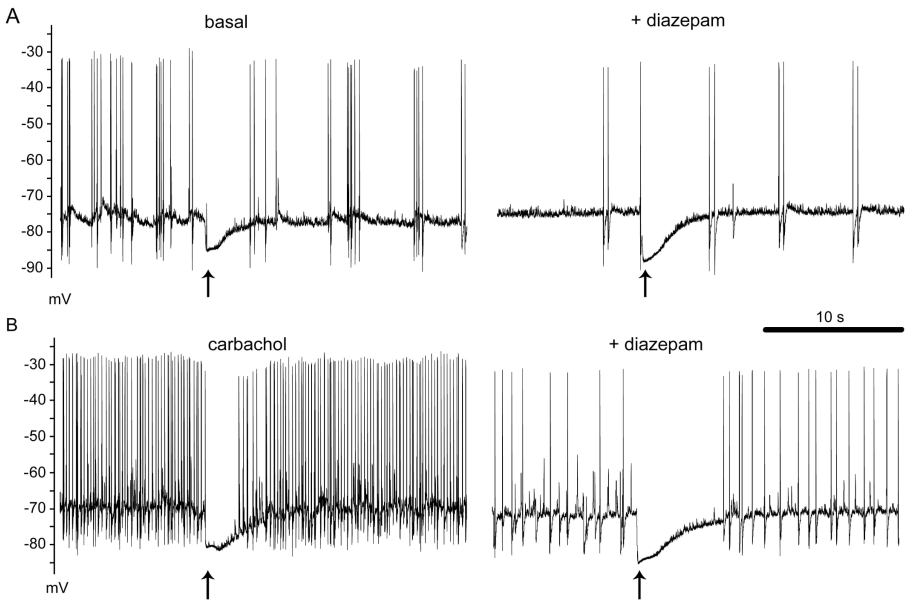

C
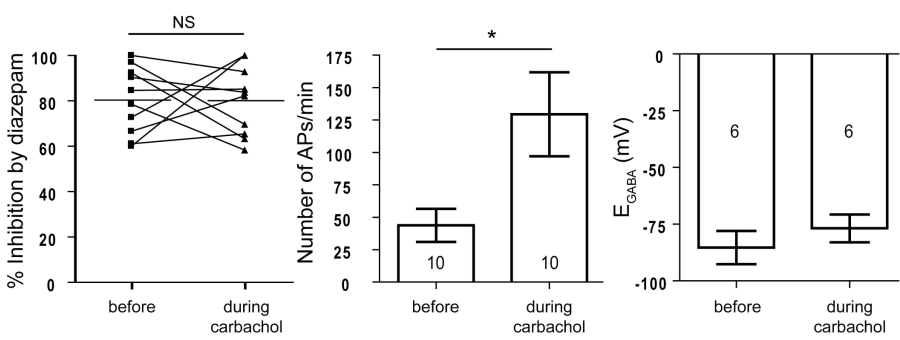

Figure 3.

Carbachol did not affect the efficacy of diazepam despite increased excitability. (A) Basal activity was suppressed by diazepam. (B) Neuronal excitability increased during the exposure to carbachol, which diazepam suppressed by a similar percentage. (C) Summary graphs of the percent inhibition by diazepam, the APs/min, and $\mathrm{E}_{\mathrm{GABA}}$ values before and during carbachol exposure. For the percent inhibition graph, sticks connect the vales before and during carbachol exposure for each neuron, while the horizontal line indicates the mean values. The $\mathrm{n}$ numbers are indicated within the APs and $\mathrm{E}_{\mathrm{GABA}}$ bars. NS indicates not statistically significant $\left(\mathrm{n}=10, t_{9}=0.04, P=0.9723\right) . *$ indicates statistical significance compared to values obtained before carbachol exposure $\left(\mathrm{n}=10, t_{9}=3.34, P=0.0086\right)$. 
A

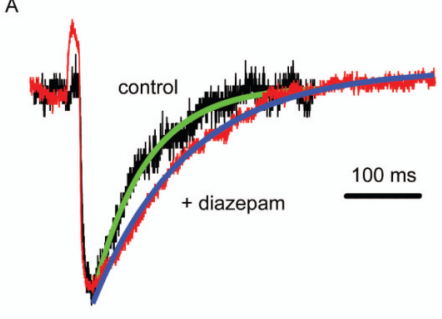

C

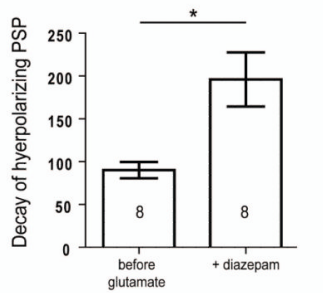

D

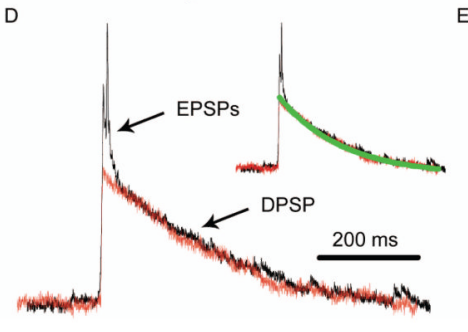

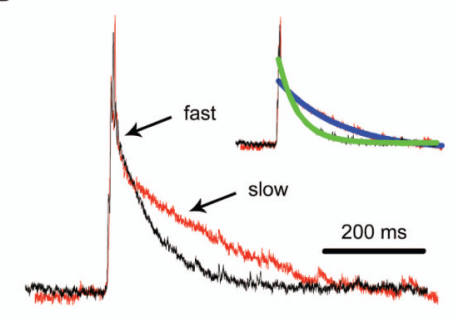
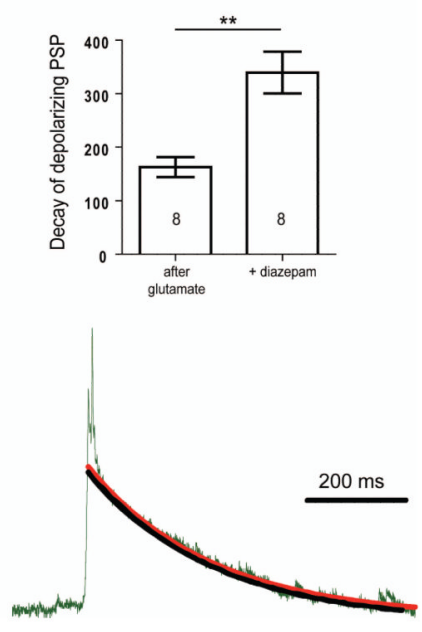

Figure 4.

Diazepam potentiated hyperpolarizing and depolarizing GABAergic PSPs. (A) GABAergic hyperpolarizing PSPs (black) were potentiated in the presence of diazepam (red). The exponential fits to each trace are superimposed for illustration. (B) Glutamate application converted the hyperpolarizing PSPs to depolarizing PSPs. Depolarizing PSPs in the absence (black) and presence of diazepam (red). Note that diazepam caused the appearance of a pronounced slow component of the PSP. The decays of both PSPs were fit with monoexponential functions, which are superimposed for display (inset). (C) Summary graphs of the decay rates of the GABAergic hyperpolarizing (left) and depolarizing (right) PSPs in the absence and presence of diazepam. The $n$ values representing the total number of neurons are indicated within the bars (see text). * indicates statistical significance between values in the absence and presence of diazepam before glutamate exposure ( $\mathrm{n}=8$ neurons, $t_{7}=4.46$, $P=0.0029)$.** indicates statistical significance between values in the absence and presence of diazepam after glutamate exposure ( $\mathrm{n}=8$ neurons, $t_{7}=7.73, P=0.0001$ ). (D) Application of the glutamatergic antagonists AP5 and DNQX revealed that the fast component of the depolarizing PSP was a diazepam-insensitive EPSP. The exponential fit to the isolated GABAergic DPSP in the presence of AP5/DNQX is superimposed on both traces (inset). (E) The black and red curves are the exponential fits from panel $\mathbf{B}$ and panel $\mathbf{D}$, and are superimposed onto the combined EPSP/DPSP. Note that the exponential fits are virtually identical. The amplitudes of the events were normalized to the peaks for comparison in all panels. 

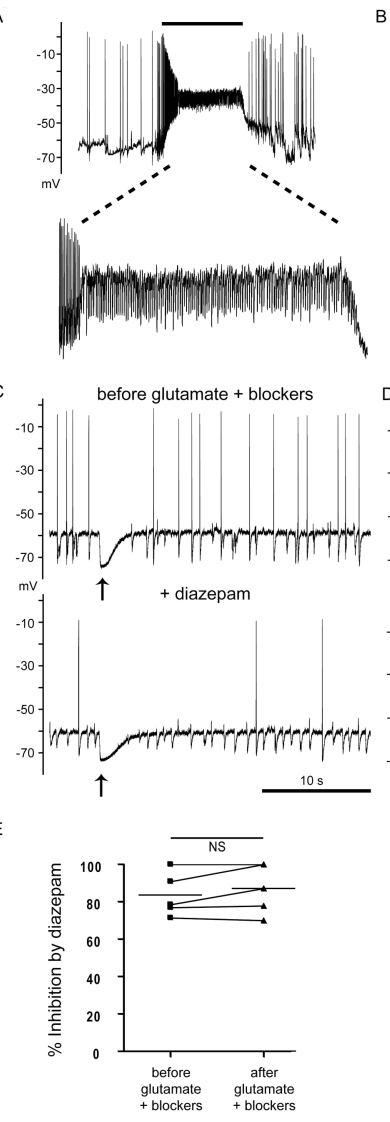

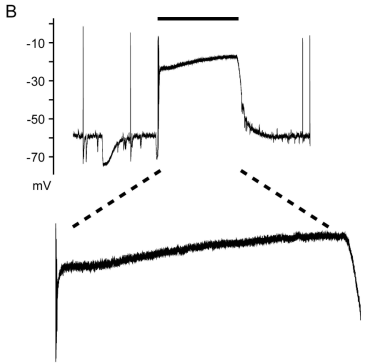

D after glutamate + blockers
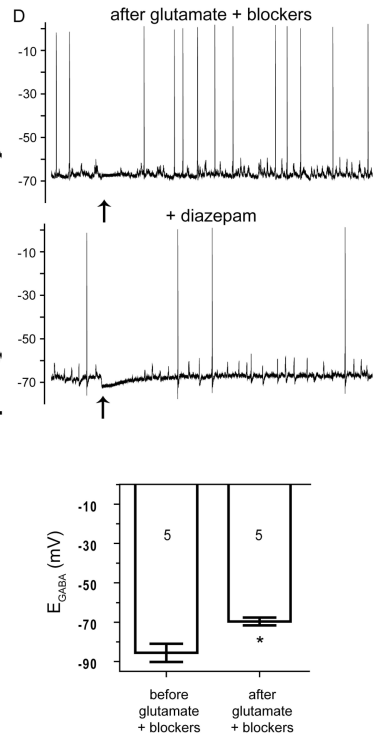

Figure 5.

The glutamate-induced $\mathrm{Cl}^{-}$load caused the reduction in diazepam's inhibitory efficacy. (A) Glutamate (10 s, black bar) depolarized the membrane potential (upper trace). Closer inspection of the depolarized phase revealed barrages of IPSPs (lower trace). (B) Application of a mixture of glutamate, bicuculline and bumetanide (10 s, black bar) also depolarized the membrane (upper trace). Closer inspection of the depolarized phase indicated that the inhibitors blocked the barrages of IPSPs (lower trace). (C) Before exposure to glutamate, bicuculline, bumetanide, the basal neuronal activity (upper trace) was suppressed by diazepam (lower trace). (D) The neuronal activity (upper trace) after exposure to glutamate, bicuculline and bumetanide was suppressed by diazepam (lower trace). Note that the muscimol response was hyperpolarizing during the diazepam application. Traces from panels B-D were from the same neuron. (E) Summary graphs of the inhibitory efficacy of diazepam (left) and $\mathrm{E}_{\mathrm{GABA}}$ values (right) obtained before and after exposure to glutamate, bumetanide and bicuculline. The $\mathrm{n}$ numbers are indicated within the $\mathrm{E}_{\mathrm{GABA}}$ bars. NS indicates not statistically significant $\left(\mathrm{n}=5, t_{4}=1.54, P=0.1979\right) . *$ indicates statistical significance compared to values obtained before glutamate exposure $\left(\mathrm{n}=5, t_{4}=4.41, P=\right.$ $0.0116)$. 


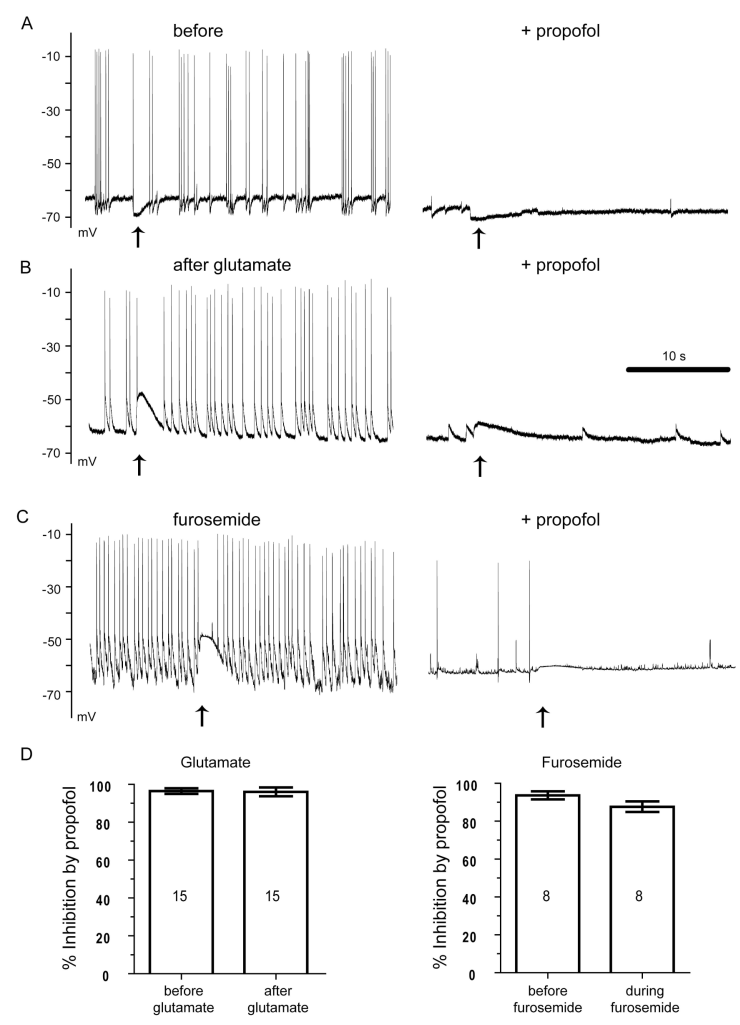

Figure 6.

The efficacy of propofol was not altered by glutamate or furosemide. (A) Basal neuronal activity (left) was strongly inhibited by propofol (right). (B) After exposure to glutamate (left), propofol still strongly inhibited activity even when muscimol was depolarizing (right). Data in panels $\mathbf{A}$ and $\mathbf{B}$ were from the same neuron. (C) After a six minute exposure to furosemide and the development of depolarizing muscimol responses (left), propofol application strongly suppressed neuronal activity (right). (D) Summary graphs of the inhibitory efficacy of propofol before and after glutamate exposure (left), and before and during furosemide exposure (right). The n numbers are indicated within each bar. 


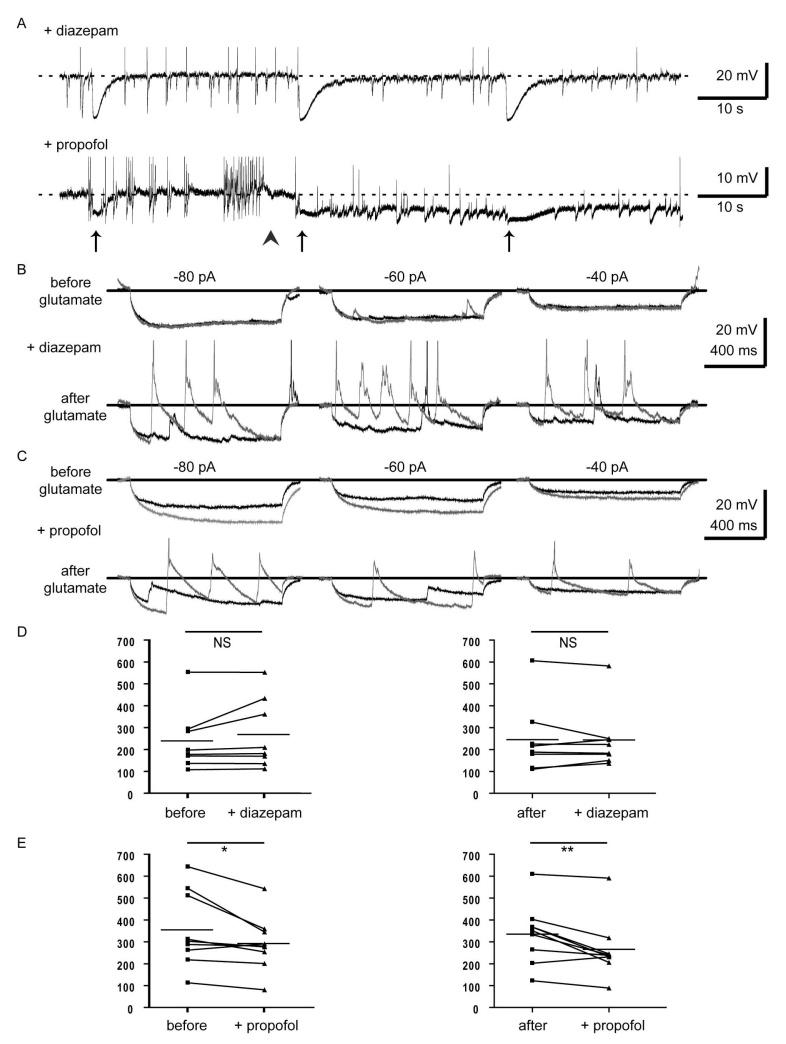

Figure 7.

Propofol but not diazepam reduced input resistance before and after glutamate exposure. (A) Application of diazepam did not affect the membrane potential (top). Application of propofol caused a rapid hyperpolarization of the membrane potential (bottom). For both traces, the arrows indicate the positions of the muscimol responses and the arrowhead indicates the onset of diazepam or propofol. The dashed lines indicate the position of the resting membrane potential to illustrate the effects of diazepam and propofol. (B) Membrane potential responses to the indicated current steps in the absence (red) and presence (black) of diazepam before (upper traces) and after exposure to glutamate (lower traces). (C) Membrane potential responses to the indicated current steps in the absence (red) and presence (black) of propofol before (upper traces) and after exposure to glutamate (lower traces). The membrane responses are superimposed to illustrate the effects of diazepam and propofol. The APs are cutoff for illustrative purposes. (D) Summary graphs of diazepam's effect on input resistance before (left) and after (right) exposure to glutamate. (E) Summary graphs of propofol's effect on input resistance before (left) and after (after) exposure to glutamate. The lines connect data points obtained for each cell. NS indicates not statistically significant before glutamate $\left(\mathrm{n}=8, t_{7}=1.60, P=0.1533\right)$ and after glutamate $\left(\mathrm{n}=8, t_{7}=\right.$ $0.15, P=0.8874)$. * indicates statistical significance between values in the absence and presence of propofol before glutamate $\left(\mathrm{n}=9, t_{8}=2.53, P=0.0352\right)$. ** indicates statistical significance between values in the absence and presence of propofol after glutamate $(\mathrm{n}=9$, $\left.t_{8}=2.53, P=0.0352\right)$. 